\title{
Redox Signaling in Neurotransmission and Cognition During Aging
}

\author{
Ashok Kumar,, Brittney Yegla,, and Thomas C. Foster ${ }^{1,2}$
}

\begin{abstract}
Significance: Oxidative stress increases in the brain with aging and neurodegenerative diseases. Previous work emphasized irreversible oxidative damage in relation to cognitive impairment. This research has evolved to consider a continuum of alterations, from redox signaling to oxidative damage, which provides a basis for understanding the onset and progression of cognitive impairment. This review provides an update on research linking redox signaling to altered function of neural circuits involved in information processing and memory. Recent Advances: Starting in middle age, redox signaling triggers changes in nervous system physiology described as senescent physiology. Hippocampal senescent physiology involves decreased cell excitability, altered synaptic plasticity, and decreased synaptic transmission. Recent studies indicate N-methyl-D-aspartate and ryanodine receptors and $\mathrm{Ca}^{2+}$ signaling molecules as molecular substrates of redox-mediated senescent physiology. Critical Issues: We review redox homeostasis mechanisms and consider the chemical character of reactive oxygen and nitrogen species and their role in regulating different transmitter systems. In this regard, senescent physiology may represent the co-opting of pathways normally responsible for feedback regulation of synaptic transmission. Furthermore, differences across transmitter systems may underlie differential vulnerability of brain regions and neuronal circuits to aging and disease.

Future Directions: It will be important to identify the intrinsic mechanisms for the shift in oxidative/reductive processes. Intrinsic mechanism will depend on the transmitter system, oxidative stressors, and expression/activity of antioxidant enzymes. In addition, it will be important to identify how intrinsic processes interact with other aging factors, including changes in inflammatory or hormonal signals. Antioxid. Redox Signal. 28, 1724-1745.
\end{abstract}

Keywords: aging, $\mathrm{Ca}^{2+}$ signaling, cognition, NMDA receptor, oxidative stress, redox regulation

\section{From Oxidative Signaling to Oxidative Stress}

$\mathbf{R}$ EACTIVE OXYGEN SPECIES (ROS) and reactive nitrogen species (RNS) are formed as a result of (a) electron transport in mitochondria during metabolism, (b) oxidase enzymatic activity associated with cell signaling, and (c) as a host defense mechanism associated with inflammation. ROS and RNS can briefly and reversibly modify protein function and thus act as signaling molecules that regulate a number of cellular processes. Oxidative stress, resulting in irreversible molecular damage, occurs as the level of ROS and RNS be- gins to exceed the capacity of the antioxidant system. The brain is highly sensitive to oxidative stress due to reliance on oxidative metabolism for energy. Relative to other organs, the brain consumes more oxygen and has relatively low levels of antioxidant enzymes (111). In addition to the level of ROS and RNS, the duration of oxidative stress, as well as the chemical character of the oxidative stressor, determines the effects of oxidative stress on the brain.

The major metabolic forms of ROS include superoxide $\left(\mathrm{O}_{2}{ }^{-}\right)$and the hydroxyl radical ( $\left.\mathrm{OH}\right)$. In most cases, highly reactive superoxide is converted to the less reactive hydrogen

\footnotetext{
${ }^{1}$ Department of Neuroscience, McKnight Brain Institute, University of Florida, Gainesville, Florida.

${ }^{2}$ Genetics and Genomics Program, Genetics Institute, University of Florida, Gainesville, Florida.
}

(C) Ashok Kumar, et al., 2018; Published by Mary Ann Liebert, Inc. This Open Access article is distributed under the terms of the Creative Commons Attribution Noncommercial License (http://creativecommons.org/licenses/by-nc/4.0), which permits any noncommercial use, distribution, and reproduction in any medium, provided the original authors and source are cited. 
peroxide $\left(\mathrm{H}_{2} \mathrm{O}_{2}\right)$ and then to water by the antioxidant enzyme system. Indeed, hydrogen peroxide is the most abundant ROS released by mitochondria (79). Hydrogen peroxide is a signaling molecule, which interacts with cysteine residues in reduction-oxidation (redox)-sensitive proteins to induce the rapid formation of disulfide bonds between cysteines or with glutathione (GSH) to form S-glutathionylated proteins (43, $208,215,235,293$ ). These disulfide bonds are easily broken by reducing agents or enzymes that depend on GSH or nicotinamide adenine dinucleotide phosphate (NADPH). For example, energy metabolism and mitochondrial function are modified by cytosolic (114) and extracellular redox signaling (128). A modest rise in hydrogen peroxide rapidly activates glucose-6-phosphate dehydrogenase to form disulfide bonds between cysteines in glyceraldehyde-3-phosphate dehydrogenase, shifting glucose metabolism from glycolysis to the pentose phosphate pathway $(20,80,222,281)$. In turn, the pentose phosphate pathway generates NADPH for redox reactions.

Similarly, nitric oxide (NO) is a free radical synthesized by nitric oxide synthase (NOS) and induces thiol S-nitrosylation of cysteine residues. Like the disulfide bonds induced by hydrogen peroxide, S-nitrosylation is rapid and reversible and acts as a signaling mechanism. However, under oxidative stress, the increased level of superoxide reacts with nitric oxide to produce the highly reactive RNS, peroxynitrite $\left(\mathrm{ONOO}^{-}\right)$.

In contrast to reversible modification induced by hydrogen peroxide and nitric oxide, the highly reactive peroxynitrite, superoxide, and hydroxyl radical produce irreversible damage to DNA (e.g., 8-hydroxy-2'-deoxyguanosine), lipids (e.g., 4hydroxy-2,3-nonenal), and proteins (e.g., carbonyls and 3nitrotyrosination) $(22,35)$. In this case, the molecules must be removed and replaced to maintain functional integrity. Similar to other organs, oxidative damage increases in the brain with age $(8,44,66,112,192,256,286)$. Age-related vulnerability to oxidative stress and the level of oxidative damage vary by brain region $(1,63,189,224,256)$. Previous work suggests that regional differences in the accumulation of damaged molecules may contribute to age-related impairment of sensory-motor function $(66,162)$ and memory impairments $(40,81,137,194,195)$. Interestingly, despite increased levels of lipid peroxidation and protein carbonylation, nitrotyrosine levels may not accumulate in the brain with age or may be increased only in selective brain regions $(44,78,154)$. Finally, for neurodegenerative diseases, levels of oxidative damage are increased above age-matched controls $(253,267)$. In some cases, the oxidative damage may be a consequence of the disease; however, evidence indicates that the products of lipid peroxidation can cause cell death (267).

\section{Redox Signaling}

Mounting evidence indicates that an oxidized redox state or redox stress precedes accumulation of oxidative damage and the shift in redox state underlies physiological characteristics of neuronal senescence $(90,102,153,207)$. A mild, yet sustained, increase in ROS/RNS levels can induce an incessant increase in the activity of redox signaling cascades to influence cell function. As such, an oxidized redox state likely represents an early marker of Alzheimer's disease by contributing to the emergence of impaired synaptic function before frank histopathology (90). Indeed, the oxidized redox state may pave the way for increasing oxidative stress and the accumulation of oxidative damage, which precedes aggregation of molecules that normally characterize neurodegenerative diseases (218). The results suggest a continuum of changes due to increasing oxidative stress with advancing age and disease (Fig. 1). As the redox state becomes increasingly oxidized, functional disruption develops, and depending on genetic or environmental factors, the oxidized redox state will contribute to the accumulation of malformed or damaged molecules.

An understanding of the role of the redox environment in cellular processes depends on the tools for measurement and manipulation of redox state. In biological systems, redox state is commonly measured as the balance of redox couples GSH/glutathione disulfide (GSSG), nicotinamide adenine dinucleotide $\left(\mathrm{NAD}^{+}\right) /(\mathrm{NADH})$, and $\mathrm{NADP}^{+} / \mathrm{NADPH}$. In most cases, GSH/GSSG is employed as the measure of redox state due to greater abundance and because GSH acts as the reducing agent for many other molecules $(103,240)$. A decline in free GSH or rise in GSSG is observed in middle age for several vulnerable brain regions, including the cortex, hippocampus, thalamus, striatum, and cerebellum $(75,212$, 223-225, 303). In contrast, the level of GSH may remain constant in the brain of animals that maintain cognitive function over the course of aging (187). Consistent with a continuum of redox changes, the decline in GSH/GSSH may precede mitochondrial dysfunction $(47,173)$. Finally, GSH levels in astrocytes are higher than those observed in neurons such that regional differences in astrocyte number or function could influence vulnerability to oxidative stress (158).

In addition to measures of GSH, the role of redox state in cell function can be tested by examining the effects of reducing and oxidizing agents on physiology. Some specificity can be achieved in identifying intracellular or extracellular redox changes by using membrane-impermeable agents, particularly oxidized or reduced GSH $(31,57,226,234,268)$. Membranepermeable oxidants include 5,5-dithio-bis-2-nitrobenzoic acid (DTNB) and hydrogen peroxide. While hydrogen peroxide lacks specificity, application of these oxidizing agents to neurons from young animals can mimic the effects of aging $(24,31,296)$. Similarly, the membrane-permeable reducing agent, dithiothreitol (DTT), has a rejuvenating effect on physiology in cells from aged animals $(31,32,42,108,144)$.

\section{Sources for ROS and RNS in the Brain}

The vulnerability of different cell types, cellular compartments, and brain regions depends on the chemical character of the oxidative stressor, level of ROS production, and expression/activity of antioxidant enzymes. Superoxide is generated in mitochondria during oxidative phosphorylation, and the production of mitochondrial superoxide and hydrogen peroxide is inversely related to longevity $(115,258)$. Due to its high reactivity, this radical does not travel far, which may limit where damage occurs. The mitochondrial free radical theory of aging suggests that the production of superoxide by mitochondria results in impaired mitochondrial function $(101,115)$. Indeed, relative to other molecules, enhanced damage to mitochondrial DNA (181) and increased mitochondrial protein carbonyls $(256,294,295)$ can be observed in models of aging and neurodegenerative diseases. However, others have not observed an age-related increase in mitochondrial damage, possibly due to differences in brain region vulnerability, rate of protein removal, or specificity 

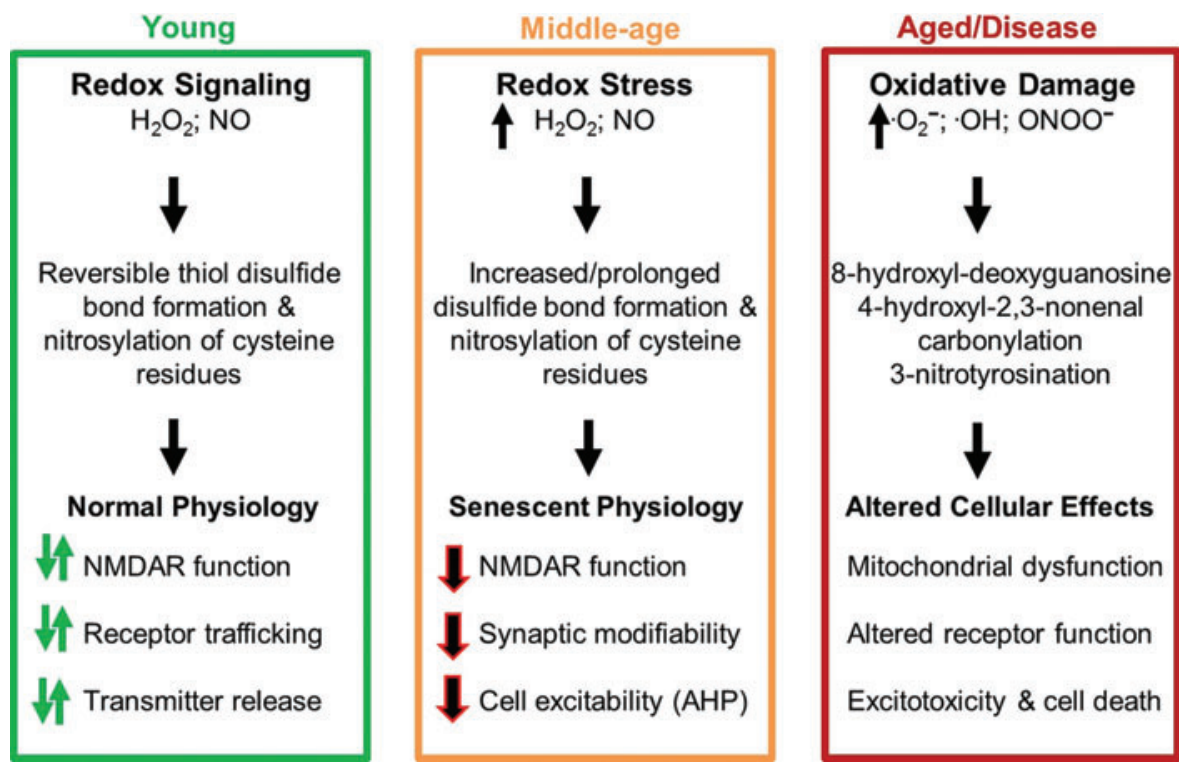

FIG. 1. Altered redox homeostasis, from signal transduction to oxidative damage, over the course of aging. In younger individuals (green box), a brief rise in hydrogen peroxide or nitric oxide acts as a signal by forming reversible disulfide bonds or S-nitrosylation to rapidly and reversibly influence synaptic function. With advancing age (orange box), increased levels of hydrogen peroxide or nitric oxide prolong or constitutively activate these signaling processes, resulting in stable physiological changes (senescent physiology). With advanced age or in neurodegenerative disease (red box), increased levels of highly reactive molecules, superoxide, peroxynitrite, and the hydroxyl radical induce the accumulation of irreversible damage, impairment in mitochondrial function and synaptic transmission, and cell death. To see this illustration in color, the reader is referred to the web version of this article at www.liebertpub.com/ars

of the cellular compartment $(68,104)$. As discussed in Antioxidant Enzymes section, increased expression of mitochondrial antioxidant enzymes decreases oxidative damage and may be protective against neurodegenerative diseases; however, decreasing mitochondrial superoxide does not appear to protect cognitive function during normal aging. Rather, treatments that influence hydrogen peroxide-mediated redox signaling may be more important for age-related cognitive decline $(123,152,153)$.

As noted above, most of the mitochondrial-generated superoxide is converted to the less reactive hydrogen peroxide. Unlike superoxide, hydrogen peroxide can readily cross membranes to travel a greater distance. However, hydrogen peroxide interacts with iron or copper to form the highly reactive hydroxyl radical. Thus, regional difference in the level of reactive metals is another factor that may contribute to specificity of oxidative damage and brain aging $(231,298$, 300). Interestingly, oligodendrocytes and microglia accumulate iron (21). Furthermore, relative to astrocytes, these glial cells exhibit reduced mitochondrial DNA repair capacity $(119,149)$, which could underlie the notable white matter damage associated with aging (77).

NADPH oxidase (NOX) provides another source for superoxide. NOX1 and NOX4 are expressed in neurons and are involved in synaptic plasticity as well as cerebral blood flow (136). NOX2 is primarily located in microglia and provides a source for superoxide associated with neuroinflammation $(55,107,172,236)$. NOX activity is increased during neuroinflammation and over the course of aging $(73,110,146$, 193), and increased NOX activity is thought to contribute to the progression of neurodegenerative diseases (54).

In the vascular system, nitration reactions can result from peroxide enzyme activity (283). In the nervous system, the formation of nitric oxide by NOS interacts with superoxide to form the highly reactive peroxynitrite, which underlies much of the neurotoxicity associated with increased production of nitric oxide (204). Normally, nitric oxide synthesis is tightly regulated such that neuronal NOS (nNOS) or endothelial NOS (eNOS) generates nitric oxide as a signaling molecule to influence synaptic function and cerebral blood flow. However, toxins and cytokines associated with inflammation initiate the generation of an inducible isoform (inducible nitric oxide synthase [iNOS]) in astrocytes and microglia (45, 46). Furthermore, increased expression of nNOS has been reported for neurodegenerative diseases (204). Thus, regional differences in neuroinflammation can shift cells from rapid and reversible redox signaling toward oxidative damage and may contribute to regional specificity in the onset or progression of brain aging and neurodegenerative diseases.

\section{Antioxidant Enzymes}

To act as a signaling molecule, ROS signals must be concluded in a timely manner. Antioxidant molecules and enzymes balance the biological activity of ROS to regulate ROS signaling and minimize toxicity. Thus, the ability to regulate the function of antioxidant defense mechanisms is a factor to consider in the onset and progression of cognitive decline associated with aging and diseases. The antioxidant enzymes include superoxide dismutase (SOD), which catalyzes superoxide into hydrogen peroxide, and catalase (CAT) or glutathione peroxidase (GPx), which convert hydrogen peroxide to water and oxygen. SODs are classified according to their metal cofactors and cellular localization. $\mathrm{Cu} / \mathrm{Zn}-\mathrm{SOD}$ (SOD1) is distributed throughout the cytoplasm, nucleus, and inner membrane space of mitochondria. $\mathrm{Cu} / \mathrm{Zn}-\mathrm{SOD}$ (SOD3) is 
located in the extracellular space, and Mn-SOD (SOD2) is restricted to the mitochondrial matrix. The literature concerning the brain expression or activity of antioxidant enzymes over the course of aging is mixed (249). For example, Cu/Zn-SOD activity is either decreased or unchanged and Mn-SOD activity is either increased or unchanged in the brain with aging.

Transgenic mice have been employed to address questions of how antioxidant enzymes contribute to oxidative damage, vulnerability to disease, and aging. Mice that exhibit knockout (SOD3) or knockdown (SOD1, SOD2) of SOD isoforms exhibit increased oxidative damage and increased vulnerability to age-related diseases, without necessarily affecting longevity or age-related cognitive decline $(27,150,188,211,247,284)$. The results suggest that a decline in SOD activity may render animals more vulnerable to age-related diseases; however, these studies leave open the question of the role of oxidative damage in cognitive decline associated with normal aging.

If superoxide and oxidative damage mediate age-related cognitive decline, then upregulation of SOD should reduce oxidative damage and be protective against aging. Upregulation of mitochondrial SOD2 reduces mitochondrial superoxide, but does not protect against cognitive decline associated with normal aging $(123,153)$. Rather, crossing mice that overexpress SOD2 with a transgenic mouse model of Alzheimer's disease indicates that SOD2 is protective against the onset of cognitive impairment associated with expression of the genes linked to Alzheimer's disease (74, 175). Again, the results are consistent with the idea that SOD activity is protective against diseases of aging and leaves open the question of the role of oxidative damage in mediating cognitive decline associated with normal aging.

In mice, overexpression of SOD1 or SOD3 impairs hippocampal-dependent memory and synaptic plasticity in adult mice $(95,156,274)$. Because these were transgenic animals, it is possible that memory changes were due to developmental influences of SOD overexpression. While expression was increased in all tissues, examination of hippocampal physiology suggested a possible SOD effect specific to hippocampal synaptic plasticity. The role of ROS in regulating synaptic plasticity has recently been reviewed (174). Briefly, long-term potentiation (LTP) is a long-term increase in synaptic transmission in response to patterned synaptic activity. LTP represents one mechanism for learning and memory, and the redox-mediated disruption of LTP during aging is thought to contribute to cognitive impairment (87). At hippocampal CA1 synapses, the induction of LTP requires a transitory increase in superoxide and induction is impaired by a sustained increase in hydrogen peroxide. In the case of SOD3 overexpression, LTP was rescued by inhibition of SOD, but not by application of CAT, suggesting that the impairment was due to a loss of superoxide signaling rather than elevated hydrogen peroxide (274). Using the radial arm maze as a test of learning and memory, it was shown that adult SOD3-overexpressing mutant mice exhibit deficits that depend on motivational state (156). With advanced age, these mutant mice exhibited improved learning and memory on the radial arm maze (157). It is curious that improved behavior was not associated with a decrease in oxidative stress in the hippocampus and was dependent on motivational state.

In contrast to SOD3, impaired LTP associated with increased SOD1 expression is thought to result from excess hydrogen peroxide $(134,152)$. The specificity of SOD1 overexpression on memory and synaptic function was examined in a series of studies that employed a viral vectormediated delivery system $(152,153)$. SOD1 expression was limited to region CA1 of the hippocampus of rats at specific ages $(152,153)$. Overexpression reduced age-related oxidative damage, indicating that increasing SOD1 activity can reverse the accumulation of damaged molecules, specifically when expressed in older animals (Fig. 2A, B). Importantly, SOD1 expression and the decrease in oxidative damage were associated with impaired cognitive function and impaired synaptic plasticity in middle-aged and aged animals (Fig. 2CE). This would seem counterintuitive that reduced oxidative damage in older animals is associated with impaired cognition and synaptic plasticity. The answer to this conundrum was revealed by examination of the redox state. In addition to decreased oxidative damage, expression of SOD1 was associated with a decrease in GSH and an increase in expression of GPx 1 . Excess hydrogen peroxide can deplete the level of GSH and initiate a compensatory increase in GPx expression $(197,230)$. The idea that SOD1 was producing excess hydrogen peroxide was confirmed by overexpression of CAT, which rescued cognition and synaptic plasticity (Fig. 2C-E). The results emphasize the contribution of hydrogen peroxide and an oxidized redox state, rather than oxidative damage, as the mechanisms for age-related cognitive impairment.

Similar to SOD, knockout and overexpression of GPx influence the susceptibility to nervous system oxidative damage, without necessarily influencing normal aging (155). Knockout of CAT is relatively benign, possibly due to compensation by GPx, although overexpression of CAT is neuroprotective against ischemia (11). Interestingly, transgenic mice, which express CAT, specifically in the mitochondria, exhibit reduced effects of aging on heart, muscle, and metabolism, as well as increased longevity $(67,151,244$, $277,280)$ and enhanced hippocampal-dependent memory (203). However, the study of hippocampal memory was limited to adult mice (5-6 months). Enhanced memory was not associated with a shift in markers of oxidative damage, suggesting a possible redox signaling mechanism. Finally, viral-mediated expression of CAT in the hippocampus provides protection from impairments associated with overexpression of SOD1 alone, and upregulation of SOD1+CAT was protective against cognitive impairments in advanced age (153). The results point to disruption of hydrogen peroxide signaling and redox state as a critical factor for agerelated cognitive decline.

\section{Redox Stress and Senescent Physiology}

\section{Senescent physiology}

Senescent physiology of the hippocampus, examined in vitro, has been well characterized as a decrease in cell excitability, altered synaptic plasticity, and decreased synaptic transmission (85-87, 89, 91, 140, 200, 273). It is important to emphasize that senescent physiology of hippocampal circuits is observed starting in middle age in association with the onset of cognitive impairments $(87,98,108,144)$. Much of the work has focused on impaired LTP as a hypothesized mechanism for age-related deficits in learning and memory $(14,71,82,83,87$, $90,91,141,249)$. As described below, there are several redoxsensitive mechanisms that underlie the decrease in cell excitability and impaired induction of LTP during aging. 
A

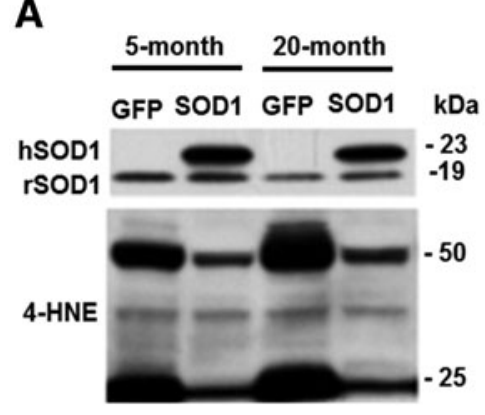

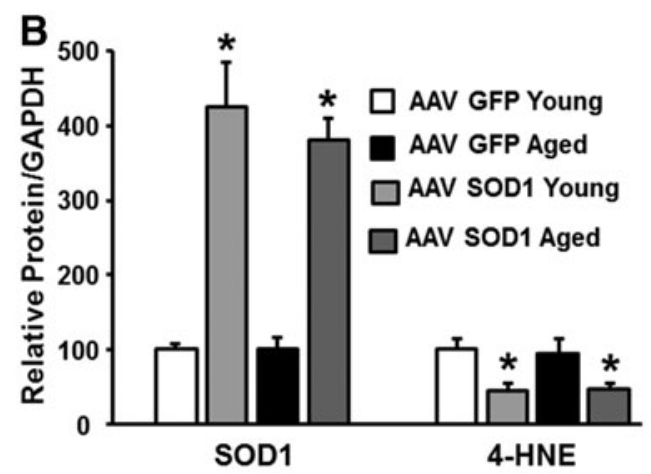

SOD1+GFP D $\square$ SOD1+CAT

C GFP
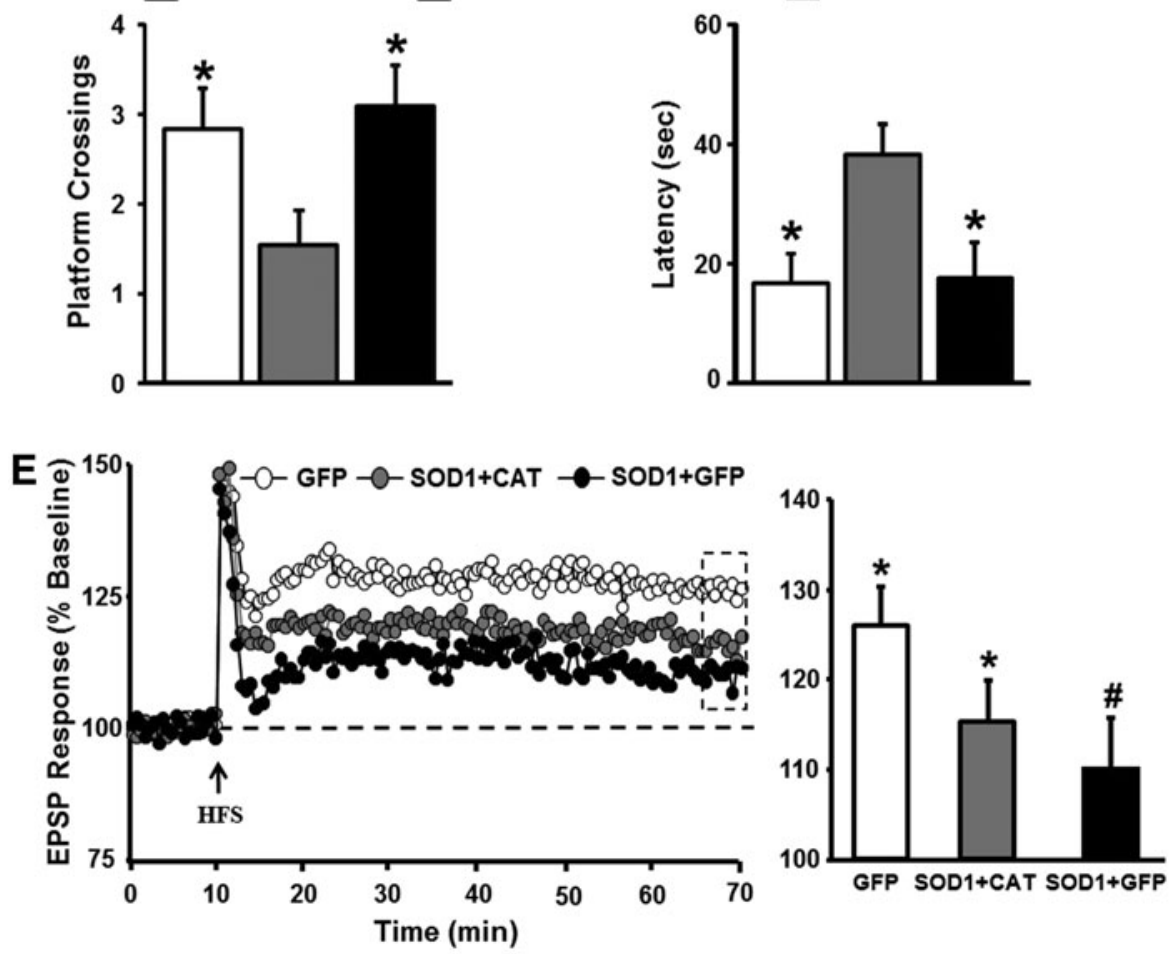

FIG. 2. Effects of increased SOD1 expression on oxidative damage, cognition, and LTP. Young (5 months) and aged (20 months) rats received hippocampal viral (adeno-associated virus [AAV]) injections to express human SOD1 or GFP. (A) Western blot illustrating that regardless of age, the viral-mediated expression of human SOD1 (hSOD1, 23 kDa) was not associated with a change in rat SOD1 (rSOD1, $19 \mathrm{kDa})$ and was associated with a decrease in lipid peroxidation measured by 4-HNE staining. (B) Quantification of Western blot measures for SOD1 expression and 4-HNE staining. Asterisk indicates a significant difference $(p<0.05)$ between rats that expressed SOD1 and GFP within each age group. (C, D) Performance of middle-aged rats (17 months) examined on the spatial water maze. Acquisition was measured as (C) the number of platform crossings and (D) latency to first platform crossing during a free swim probe trial delivered immediately after training. Compared with middle-aged rats (17 months) that expressed GFP alone (filled bars), expression of SOD1+GFP (gray bars) resulted in an impairment that was rescued by expression of SOD1+CAT (open bars). (C, D) Asterisk indicates a difference relative to SOD1+GFP animals. (E) Time course of LTP. LTP was measured as a change, relative to baseline, in the EPSP, examined $60 \mathrm{~min}$ (boxed area) after high-frequency LTP-inducing stimulation (HFS). The bar graph indicates the magnitude of LTP at $60 \mathrm{~min}$. LTP was induced in slices that expressed GFP and SOD1+CAT (asterisk $=$ significant difference from baseline). In contrast, the response for SOD1+GFP animals did not differ from baseline and was decreased relative to GFP controls (pound sign=significant difference from GFP). 4-HNE, 4hydroxynonenal; CAT, catalase; EPSP, excitatory postsynaptic potential; GFP, green fluorescent protein; LTP, long-term potentiation; SOD, superoxide dismutase. Figures adapted from Lee et al. $(152,153)$.

\section{Redox sensitivity of $N$-methyl-D-aspartate receptor function}

N-methyl-D-aspartate (NMDA) receptor activity is critical for induction of LTP, and NMDA receptor hypofunction is observed with advancing age (Fig. 3A, B). The effect of oxidizing and reducing agents on NMDA receptor responses is age dependent such that oxidizing agent, xanthine/xanthine oxidase or hydrogen peroxide, induces a decrease in the NMDA receptor synaptic response in hippocampal slices 

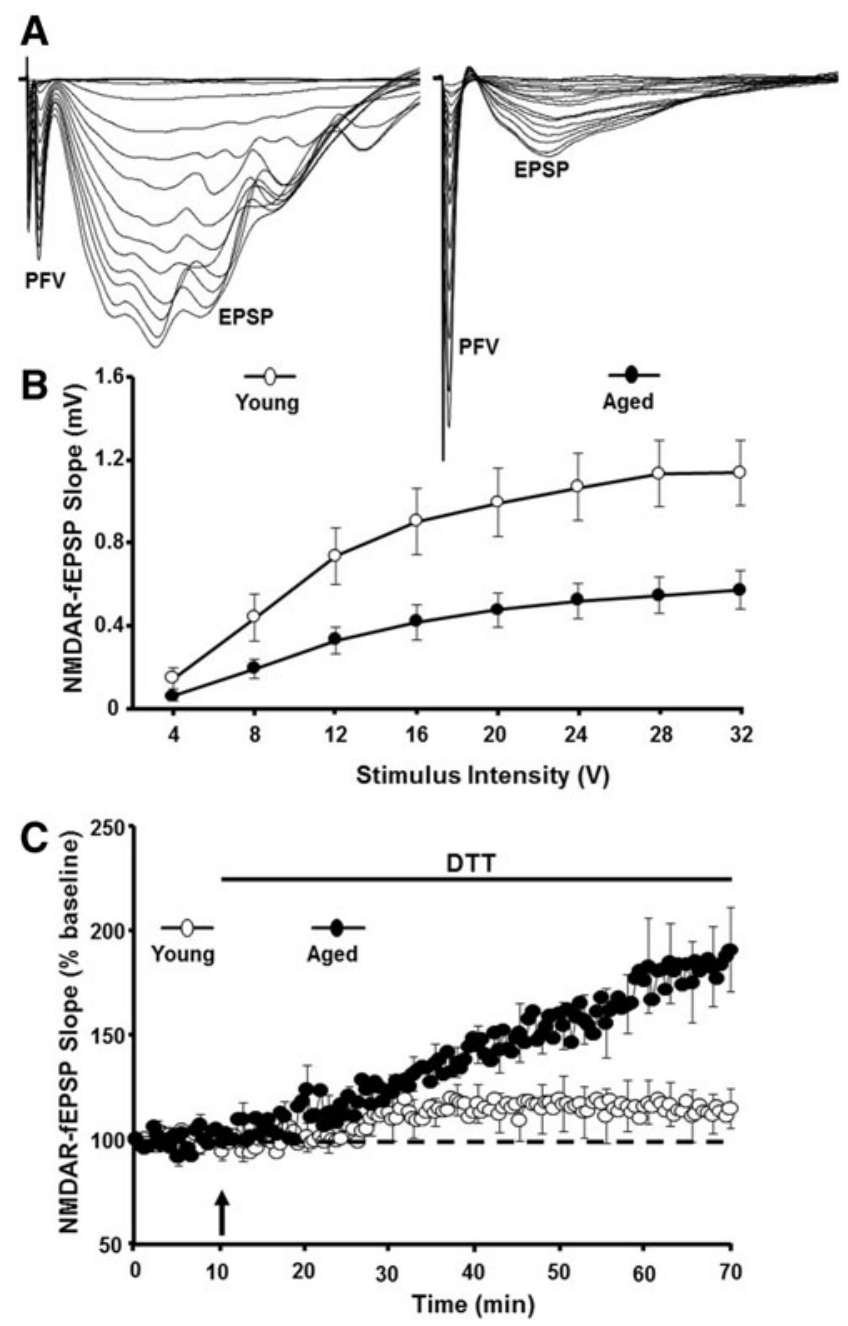

FIG. 3. Redox-mediated NMDA receptor hypofunction during aging. (A) Illustration of the PFV and the NMDAR component of CA3-CA1 field EPSPs recorded from a young rat $(l e f t)$ and the decrease in the EPSP response in an aged rat (right). (B) Input-output curve plotting the stimulation intensity delivered to the CA3 to CA1 fibers and the initial slope of the evoked NMDAR field for young (open circles) and aged (filled circles) animals. (C) Following recording of a stable baseline response, application of the reducing agent, DTT (arrow), markedly increased the NMDAR response for aged animals (filled circles) relative to young (open circles). DTT, dithiothreitol; NMDA, N-methyl-D-aspartate; NMDAR, NMDA receptor; PFV, presynaptic fiber volley. Figures adapted from Bodhinathan et al. (31).

from young animals $(3,4,24,31,160,272)$. In contrast, bath application of the reducing agent DTT enhances NMDA receptor synaptic responses specifically in older animals (31, 108, 144, 152) (Fig. 3C).

Several studies have linked a redox-mediated NMDA receptor hypofunction with age-associated cognitive impairment $(108,144,152)$. First, the decline in NMDA receptor-mediated synaptic transmission in the hippocampus and prefrontal cortex (PFC) is observed in middle-aged rats that exhibit deficits on tasks dependent on these regions. In addition, the magnitude of DTT-induced growth of the NMDA receptor synaptic response at CA3-CA1 and PFC synapses correlates with impaired spatial memory and executive function $(108,144)$. The fact that the NMDA response can be enhanced by DTT suggests that hydrogen peroxide and an oxidized redox state mediate the NMDA receptor hypofunction. This was confirmed by viral expression of SOD1, which impaired cognitive function and promoted senescent physiology observed as a DTT-sensitive decrease in the NMDA receptor-mediated synaptic response (152). Finally, viral expression of CAT rescued the NMDA receptor hypofunction in aged animals and in young overexpressing SOD1, indicating that excess hydrogen peroxide mediates impaired NMDA receptor function in senescence $(152,153)$.

There are several redox mechanisms for regulation of NMDA receptor function. For example, NMDA receptors contain extracellular cysteine residues, which may interact under oxidizing condition to form disulfide bonds, decreasing receptor function through a shift in receptor confirmation (160). However, in the case of aging, an increase in NMDA receptor function is observed when reduced GSH is delivered intracellularly and is not observed following extracellular application of GSH (31) (Fig. 4). Furthermore, NMDA receptor hypofunction is not ameliorated by antioxidants vitamin $\mathrm{C}$ and the vitamin $\mathrm{E}$ analog, trolox, which would be expected to reduce membrane and extracellular oxidative stress (296). However, NMDA receptor hypofunction can be reversed by dietary supplementation with the GSH precursor, $\mathrm{N}$-acetylcysteine $(117,227)$. These results support the idea that intracellular redox state, rather than oxidative damage of the membrane, mediates NMDA receptor hypofunction.

Using various phosphatase and kinase inhibitors, we observed that the DTT-mediated enhancement of the NMDA receptor response was blocked by specific inhibition of $\mathrm{Ca}^{2+}$ / calmodulin-dependent protein kinase II (CaMKII) activity (Fig. 5). Moreover, using cytosolic extracts, we observed that DTT increased CaMKII activity in an age-dependent manner (31) (Fig. 5C). Likely candidates for redox modulation of CaMKII activity include cysteines on CaMKII, calmodulin, and neurogranin. Recent reports indicate that prolonged exposure to nitric oxide inhibits CaMKII through S-nitrosylation of CaMKII $(60,259)$. Calmodulin is also sensitive to redox state $(26,257)$ and oxidation of calmodulin would limit CaMKII activation and subsequent CaMKII regulation of NMDA receptor function $(31,228)$. In addition, neurogranin binds calmodulin to localize it near the synapse, and this binding is reduced by redox-mediated formation of neurogranin disulfide bonds $(124,171,252)$, which could limit the responsiveness of calmodulin signaling.

Under normal physiological conditions, NMDA receptor activity induces the production of nitric oxide, which can give feedback to reduce NMDA receptor activity through Snitrosylation of cysteines on NMDA receptor subunits, NR1 and NR2A (160), and a prolonged increase in nitric oxide can reduce CaMKII activity $(60,259)$, which would decrease NMDA activity (31). However, with increased oxidative stress, production of nitric oxide through NMDA receptor activation can induce the formation of peroxynitrite and neurotoxicity associated with oxidative damage (159). In addition, as oxidative damage accumulates, NMDA receptor hypofunction may reverse. In cultured neurons, addition of the lipid peroxidation product, 4-hydroxynonenal (4-HNE), rapidly enhanced NMDA receptor responses (165). The increased $\mathrm{Ca}^{2+}$ from NMDA receptors may underlie the enhanced induction of LTP 

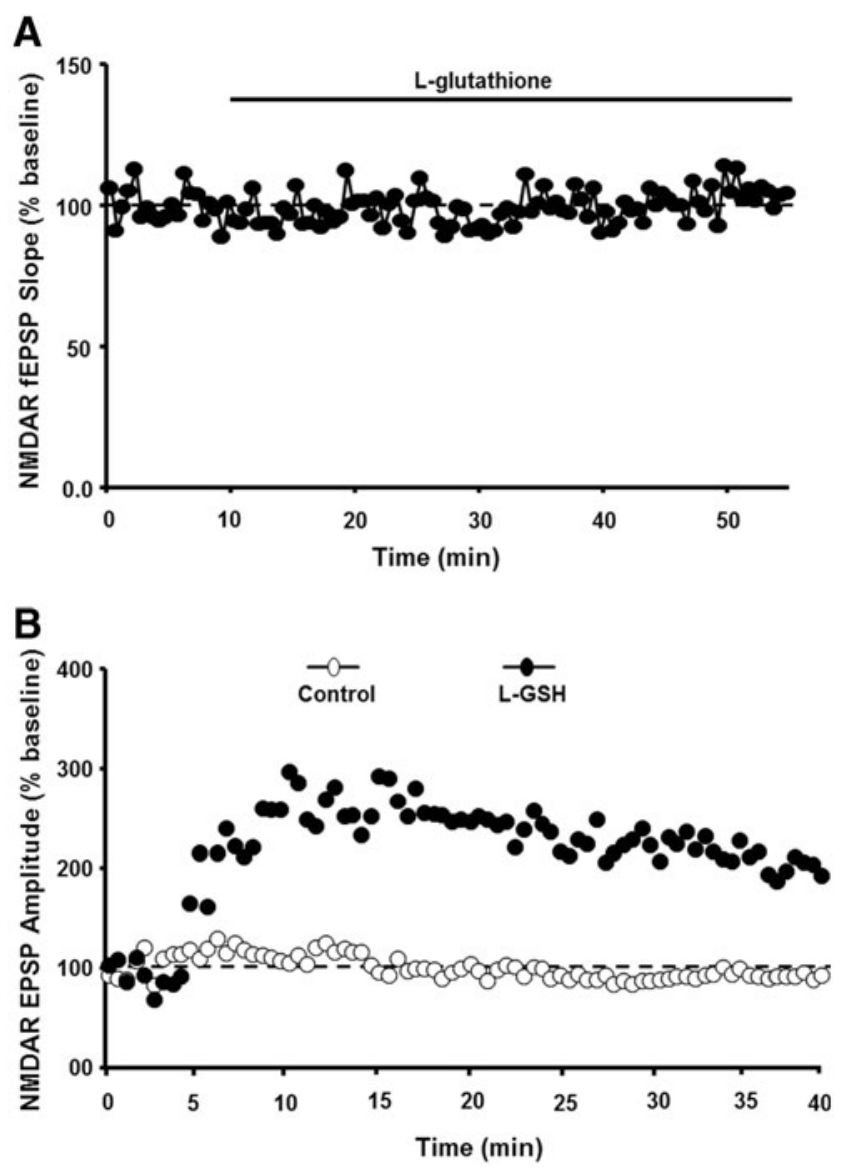

FIG. 4. Age-related NMDA receptor hypofunction is due to an oxidized intracellular redox state. (A) Application of the reduced form of GSH to the extracellular bath did not alter the NMDAR EPSP in aged animals. (B) In contrast, for intracellular recordings, including GSH in the intracellular recording pipette (filled circles) increased the NMDAR response. This increase was not observed under control conditions (open circles). Figures adapted from Bodhinathan et al. (31). GSH, glutathione.

in the dentate gyrus following 4-HNE application to hippocampal slices $(5,6)$. If $4-\mathrm{HNE}$ influences NMDA receptor function during aging, then it might be expected that effects of 4-HNE on LTP would be occluded in aged animals; however, this has not been investigated.

\section{Redox sensitivity of intracellular $\mathrm{Ca}^{2+}$ stores}

The other major characteristic of senescent neurons, a decrease in cell excitability, involves an increase in the magnitude of slow, $\mathrm{Ca}^{2+}$-dependent $\mathrm{K}^{+}$-mediated afterhyperpolarization (sAHP) $(32,98,141,142,147,186,275)$. Several pieces of evidence indicate that the age-related increase in sAHP (Fig. 6A) results from a redox-mediated increase in $\mathrm{Ca}^{2+}$ release from intracellular $\mathrm{Ca}^{2+}$ stores (ICS) (32). Evidence for redox regulation of the sAHP amplitude comes from studies that observe age-dependent effects of reducing and oxidizing agents on sAHP. First, DTT application reduced the sAHP amplitude $(\sim 50 \%)$, specifically in aged cells, such that sAHP was similar to that of young cells (Fig. 6A, B). Second, increasing oxidative stress through the
A

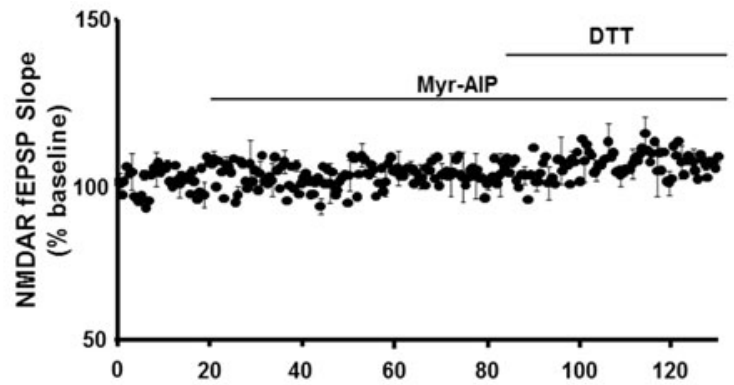

B

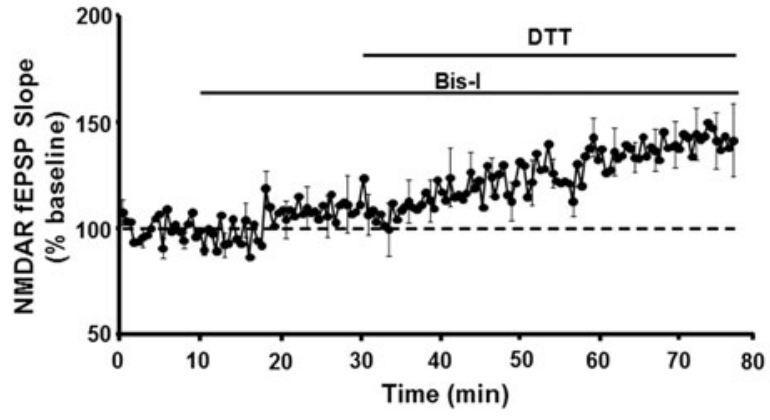

C

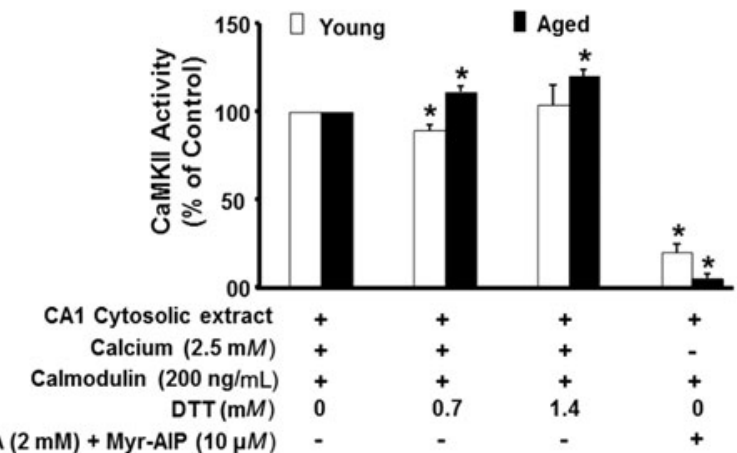

FIG. 5. Redox regulation of NMDA receptor function is linked to CaMKII. (A) Inhibition of CaMKII with MyrAIP blocked the ability of DTT to increase the NMDAR field potential EPSP in aged animals. (B) Inhibition of PKC with Bis-I failed to block the DTT-mediated growth of NMDAR synaptic potential. (C) CaMKII activity is increased by DTT in an age-dependent manner. The control condition for each age group involved 0 DTT and $2.5 \mathrm{~m} M \mathrm{Ca}^{2+}$. Asterisk indicates difference relative to the control within each age group. CaMKII, $\mathrm{Ca}^{2+} /$ calmodulin-dependent protein kinase II. Figures adapted from Bodhinathan et al. (31).

application of xanthine/xanthine oxidase mimicked the effects of aging, increasing sAHP in young animals (Fig. 6C). The specificity and magnitude of DTT effects on sAHP suggest that redox stress mediates age differences in SAHP (32).

The redox mechanism involves ICS such that decreasing $\mathrm{Ca}^{2+}$ release from intracellular stores through depletion of intracellular stores by thapsigargin or blockade of release by ryanodine prevented DTT-mediated reduction of SAHP (Fig. 7A, B). In contrast, blockade of voltage-dependent Lchannels reduces the magnitude of SAHP by $\sim 30 \%$ in young and aged rats $(199,217)$, and L-channel blockade did not occlude the effects of DTT (Fig. 7C). The results are consistent with the finding that cysteine residues within the ryanodine receptor are highly sensitive to redox conditions, 

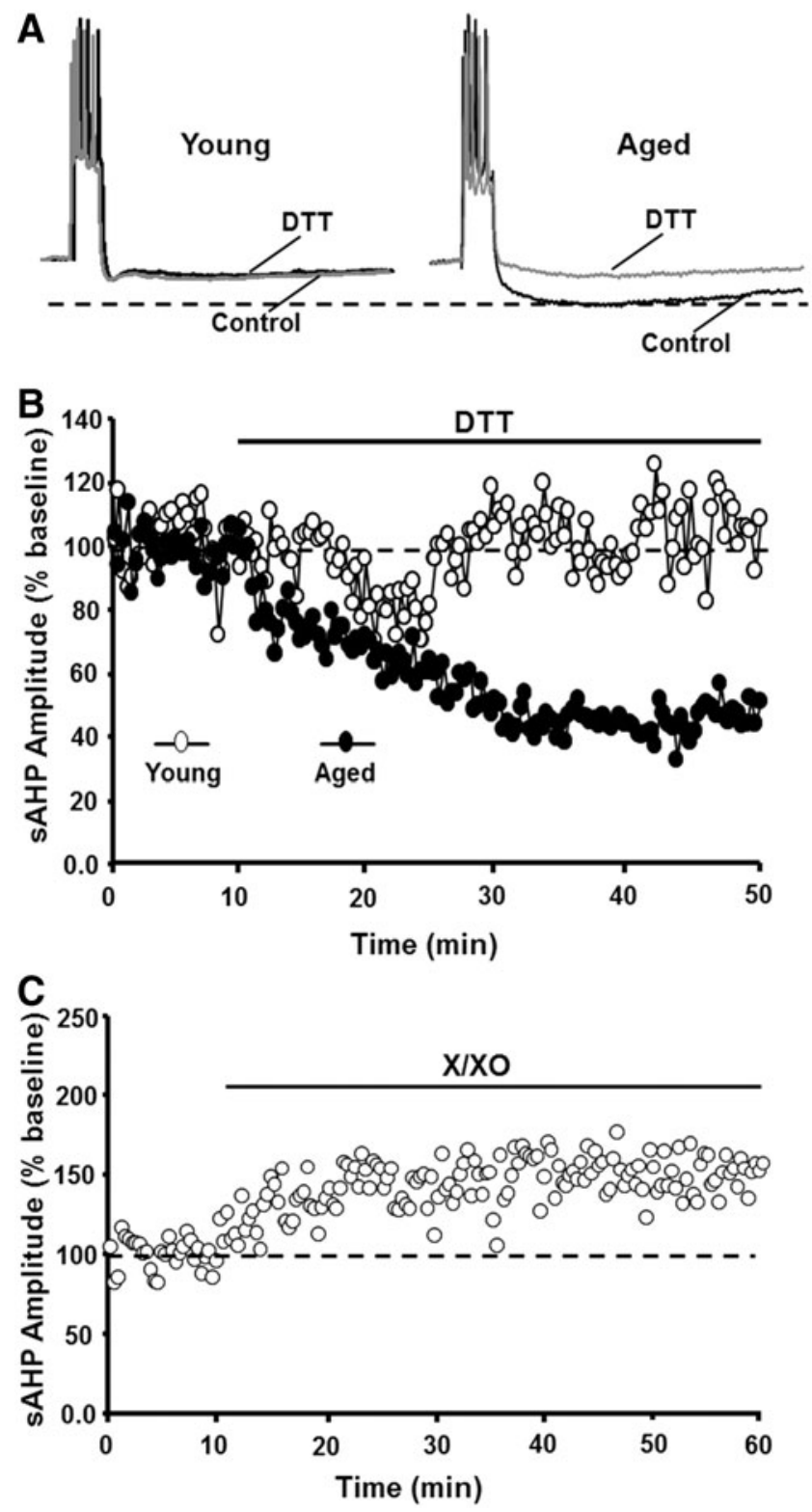

FIG. 6. An oxidized redox state mediates the agerelated increase in SAHP. (A) Illustration of sAHP elicited by a $100 \mathrm{~ms}$ depolarization to evoke five action potentials. The dashed line indicates that under control conditions (dark traces), sAHP is larger for aged animals. Application of DTT (gray traces) reduced sAHP in aged animals such that the amplitude was similar to that in young. (B) Time course of the change in sAHP following DTT application. Note that DTT decreased sAHP by $\sim 50 \%$ in aged (filled circles), but not in young (open circles), animals. (C) Application of X/XO increased the sAHP amplitude in young animals. SAHP, slow afterhyperpolarization; $\mathrm{X} / \mathrm{XO}$, xanthine/xanthine oxidase. Figures adapted from Bodhinathan et al. (32).

indicating that an oxidized redox state underlies increased release of $\mathrm{Ca}^{2+}$ from ICS (209). Finally, addition of 4-HNE to hippocampal cell cultures increased the activity of voltage-dependent $\mathrm{Ca}^{2+}$ channels, suggesting that accumulation of oxidative damage during aging or during progression of neurodegenerative diseases could further alter $\mathrm{Ca}^{2+}$ regulation (164).
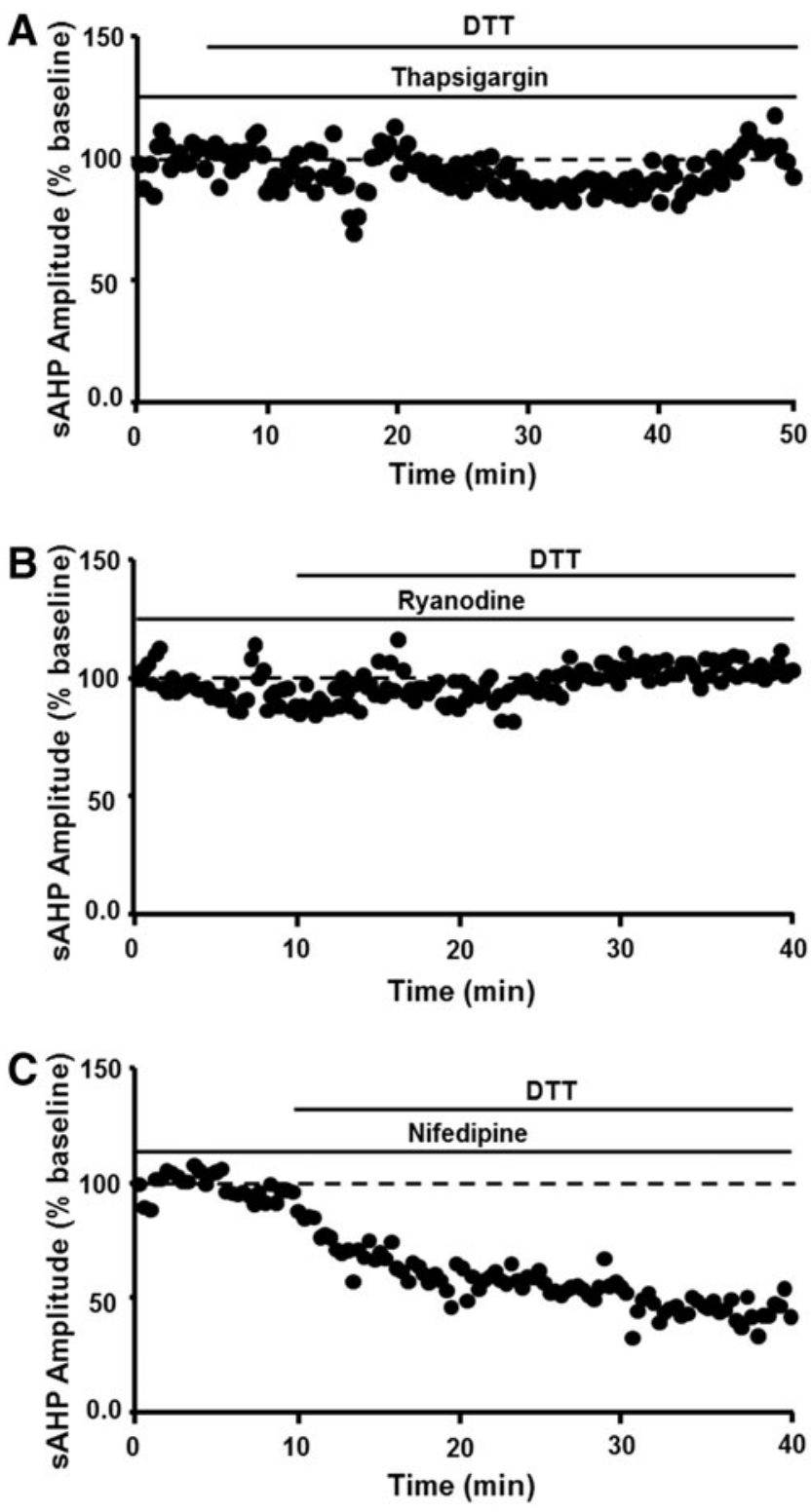

FIG. 7. The age-related increase in SAHP depends on redox regulation of $\mathrm{Ca}^{2+}$ release from intracellular stores. Decreasing $\mathrm{Ca}^{2+}$ release by (A) depletion of intracellular stores through thapsigargin or (B) RyR blockade prevents the DTT-mediated decrease in sAHP. (C) Blockade of VDCCs with nifedipine failed to inhibit the effects of DTT. RyRs, ryanodine receptors; VDCCs, voltage-dependent $\mathrm{Ca}^{2+}$ channels. Figures adapted from Bodhinathan et al. (32).

It might be expected that a decrease in cell excitability would lower cell discharge rates. However, for the CA1 region, the level of discharge activity of pyramidal cells recorded in behaving animals is not dramatically altered during aging $(39,178,202)$. Rather, aged cognitively impaired animals exhibit a deficiency in the ability to modify firing or maintain changes in firing associated with learning and memory. It is likely that the loss of modifiability is due to redox-mediated impairment in synaptic plasticity. In the case of sAHP, greater hyperpolarization disrupts the integration of depolarizing postsynaptic potentials needed to activate NMDA receptors for induction of LTP, and treatments to 
reduce sAHP unmask LTP in aged animals $(31,143,199)$. Thus, the oxidized redox state impairs synaptic plasticity either directly through NMDA receptor hypofunction or indirectly through hyperpolarization, which would limit NMDA receptor activation. Again, physiology may change as oxidative stress increases and oxidative damage accumulates. There is an indication that lipid peroxidation is associated with an overall decrease in discharge activity of hippocampal CA3 neurons recorded in awake rats (251). Regardless, results suggest that the emergence of cognitive deficits is associated with the rise in an oxidized redox state, which impairs synaptic plasticity, decreases synaptic throughput, reduces the modifiability of cell discharge activity, and the accumulation of oxidative damage may further compromise cognitive function.

\section{Redox Regulation of Neurotransmitter Systems}

Progression of functional alterations related to the level of oxidative stress is evident in several neurotransmitter systems. In some cases, the activity of the transmitter will influence redox state and, under physiological conditions, the shift in redox state can act as a rapid and reversible feedback mechanism on transmitter activity, influencing transmitter release and receptor function. Senescent physiology may represent the co-opting of redox signaling pathways, which are normally responsible for feedback regulation of synaptic transmission. In the case of the NMDA receptor, a mild increase in oxidative stress during aging may result in a constitutive or prolonged activation of these feedback mechanisms, resulting in senescent physiology (Fig. 8). Finally, the site of redox modification on vulnerable molecules may undergo oxidative damage, resulting in an irreversible inhibitory action on proteins involved in synaptic transmission, as well as promoting mitochondrial dysfunction and excitotoxicity associated with neurodegenerative diseases (Figs. 1 and 8). Below are a few examples that emphasize the role of the transmitter system in regulating ROS and the range of changes associated with increasing oxidative stress.

\section{Glutamate}

Glutamate is the main excitatory transmitter of the central nervous system and acts on metabotropic and ionotropic receptors, including the NMDA receptor. Both NMDA receptor activation (36) and blockade (19) are reported to induce oxidative stress through an increase in NOX activity. As detailed above, increased ROS results in NMDA receptor hypofunction and the production of nitric oxide can reduce NMDA receptor activity through $S$-nitrosylation of cysteines on NMDA receptor subunits. Similarly, S-nitrosylation of serine racemase inhibits formation of the NMDA receptor coagonist, D-serine, which would decrease NMDA receptor activity $(191,269)$. Under normal physiological conditions, the timely inhibition of synaptic plasticity through NMDA receptor hypofunction may play a role in maintaining memory. In this case, changes in glutamatergic synaptic transmission induced during a learning episode may be preserved by shifting the threshold for subsequent synaptic plasticity. However, in the case of increased production of nitric oxide or hydrogen peroxide during aging or diseases, reduction in NMDA receptor function could inhibit the initial synaptic plasticity required for learning (Fig. 8).

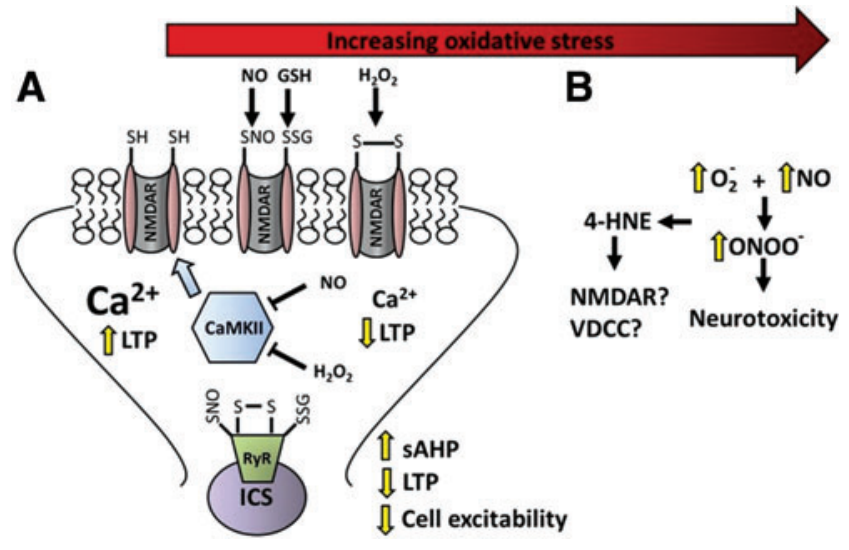

FIG. 8. Molecular mechanisms for progression from normal to senescent physiology and neurotoxicity with increasing oxidative stress. (A) Binding of glutamate and postsynaptic depolarization results in NMDAR activation and an influx of $\mathrm{Ca}^{2+}$ to induce LTP. The increase in intracellular $\mathrm{Ca}^{2+}$ initiates a modest and reversible increase in ROS, nitric oxoide (NO), and/or hydrogen peroxide $\left(\mathrm{H}_{2} \mathrm{O}_{2}\right)$. In turn, ROS interacts with redox-sensitive cysteines to induce reversible formation of disulfide bonds, S-glutathionylation, or S-nitrosylation (SNO), inhibiting NMDAR activity. The temporary reduction in NMDAR activity may permit the stabilization of synaptic plasticity during learning. If ROS levels are prolonged, NMDARs remain hyporesponsive due to redox changes at the NMDAR and reduced activity of CaMKII. Similar redox modifications of RyRs increase release of $\mathrm{Ca}^{2+}$ from ICS, increasing the amplitude of sAHP. In turn, the sustained hyperpolarizing response further inhibits voltagedependent NMDAR activation, contributing to impaired LTP induction. (B) As oxidative stress increases, lipid peroxidation and the formation of 4-HNE may have effects on NMDARs and VDCCs that result in a further dysregulation of $\mathrm{Ca}^{2+}$ homeostasis. In addition, increased levels of superoxide and the formation of peroxynitrite produce oxidative damage of vulnerable molecules, resulting in an irreversible inhibitory action on proteins and neurotoxicity. ICS, intracellular $\mathrm{Ca}^{2+}$ stores; ROS, reactive oxygen species. To see this illustration in color, the reader is referred to the web version of this article at www.liebertpub.com/ars

In addition to NMDA receptors, $\alpha$-amino-3-hydroxy-5methyl-4-isoxazolepropionic acid (AMPA) receptors represent the other major class of ionic glutamate receptors. Under physiological conditions, protein S-nitrosylation influences the surface expression of AMPA receptor subunits, GluR1 and GluR2, at the synapse $(125,245,260)$. N-ethylmaleimidesensitive factor is also redox sensitive and involved in delivery of AMPA receptors to the membrane (176). Synaptic transmission mediated by AMPA receptors is decreased with age and its attenuation is associated with cognitive impairment (144). However, AMPA receptor function is not altered by DTT, suggesting that the decrease is not directly related to redox state (31). Furthermore, application of 4-HNE does not alter the AMPA receptor synaptic response, suggesting that oxidative damage of membrane lipids does not influence AMPA receptor-mediated synaptic transmission (165). Rather, the decrease in AMPA receptor-mediated synaptic transmission during aging is ancillary to NMDA receptor hypofunction and impaired synaptic plasticity. As such, the decrease in AMPA receptor synaptic transmission is associated 
with a shift in the activity of kinases/phosphatases that mediate NMDA receptor-dependent synaptic plasticity, indicating a decrease in the endogenous level of LTP of older animals $(92,198)$.

Under normal physiological conditions, nitric oxide is generated by NMDA receptor-mediated activation of nNOS (99). In turn, nitric oxide regulates glutamate metabolism, the release of glutamate at the synapse, and transport out of the synapse $(35,221)$. An increase in protein S-nitrosylation can prolong inhibition of glutamate release, decreasing synaptic strength (232). This inhibition of glutamate release may represent a protective feedback mechanism since glutamate transporters and the removal of glutamate from the synapse are also inhibited by oxidizing conditions (hydrogen peroxide or DTNB) (279). Importantly, inhibition of glutamate uptake by an oxidized redox state is readily reversible by DTT. In contrast, with high levels of oxidative/nitrosative stress, inhibition of uptake by peroxynitrite is not reversed by DTT. Thus, an oxidized redox state would inhibit glutamatergic transmission; however, a rise in reactive ROS/RNS during ischemia or neurodegenerative diseases would result in oxidative damage and excess or prolonged glutamate in the synapse and overactivation of glutamate receptors, contributing to excitotoxicity of neurons and glia $(33,56,177)$.

\section{Gamma-aminobutyric acid}

Gamma-aminobutyric acid (GABA) is the main inhibitory transmitter in the central nervous system, and GABAergic synaptic transmission is modified by several redox-sensitive mechanisms. In the case of GABA receptor function, redox state may have opposing effects on $\mathrm{GABA}_{\mathrm{B}}$ and $\mathrm{GABA}_{\mathrm{A}}$ receptors. The response of $\mathrm{GABA}_{\mathrm{B}}$ receptors may be decreased under reducing conditions $(49,96)$, and $\mathrm{GABA}_{\mathrm{B}^{-}}$ coupled $\mathrm{K}^{+}$channels are altered by intracellular redox state (301). Like synaptic NMDA receptors, synaptic $\mathrm{GABA}_{\mathrm{A}}$ receptor function recorded in vitro can be weakened under oxidizing conditions $(10,205)$; however, in the hippocampus, tonic currents are increased by hydrogen peroxide (210). Nitric oxide is thought to inhibit tonic and phasic GABAergic responses in the hippocampus (100), and S-nitrosylation of the GABA receptor scaffolding protein, gephyrin, reduces the surface expression of $\mathrm{GABA}_{\mathrm{A}}(70)$.

There is no consensus concerning the influence of oxidative stress on GABA release, which may depend on the brain region examined (35). For example, mounting evidence suggests that redox changes of NMDA receptor synaptic input to inhibitory interneurons can decrease the release of GABA and induce the loss of inhibitory interneurons in the PFC. Indeed, NMDA receptor hypofunction and the loss of GABAergic neurons form the basis for recent models of schizophrenia $(19,161,289)$. Electrophysiological recordings indicate that activity-dependent NMDA receptor channel blockers reduce the discharge activity of the fast-spiking interneurons, in turn releasing cortical pyramidal cells from inhibition (120, 216). Furthermore, NMDA receptor antagonists induce a persistent increase in ROS through NOX activation, and the increase in oxidative stress results in the loss of fast-spiking inhibitory neurons (19). Thus, a redoxmediated NMDA receptor hypofunction could shift the balance of excitatory/inhibitory synaptic activity in the PFC. The shift in balance of excitatory/inhibitory synaptic activity may contribute to increased activation of the PFC in older individuals (77) and increased expression of activity-related genes in the PFC of aged animals that are impaired on PFCdependent tasks (127). It is not clear if a similar mechanism occurs in other brain regions; however, the ability of NMDA receptors to drive GABA release in the hippocampus is redox sensitive (129).

Finally, oxidative damage can decrease the synthesis of GABA. Normally, glutamine synthase in astrocytes converts glutamate to glutamine. The glutamine is then transported to neurons where it is used in the synthesis of glutamate and GABA. Aging and Alzheimer's disease are associated with carbonyl modification of glutamine synthase $(50,214)$. Moreover, regional vulnerability exists such that the decrease in glutamine synthase activity is particularly evident in the frontal cortex (256) and hippocampus (229).

\section{Catecholamines}

High concentrations of dopamine (DA) are associated with neurotoxicity via shifts in redox homeostasis $(116,182)$. In particular, catabolism of DA shifts the cellular redox state toward oxidative stress through the production of superoxide, hydrogen peroxide, quinones, and quinoprotein adducts (166, $183,305)$. Monoamine oxidase catalyzes the oxidation of DA to form hydrogen peroxide and DA undergoes nonenzymatic oxidation to produce DA-o-quinone, which acts on cysteinyl proteins forming quinoprotein adducts. DA metabolites also interact with trace metals, such as $\mathrm{Fe}(\mathrm{III})$ and $\mathrm{Cu}(\mathrm{II})$, within cells to produce additional ROS and further exacerbate redox imbalance $(261,305)$. The level of ROS, accumulation of adducts, and DNA damage increased by DA transporter activity $(76,292)$. Once DA is transported into the cell, it can be oxidized by monoamine oxidase, inordinately influencing accumulation of adducts in dopaminergic cells (287). Thus, regions rich in DA may exhibit increased vulnerability to ROS and quinoprotein adducts. In aging, levels of monoamine oxidase and quinoprotein adducts increase in the brain with significant adduct expression in the substantia nigra pars compacta and, to a lesser extent, the PFC and caudate nucleus (9, 133, 196, 287). In addition, levels of iron and ferritin, which store iron, are both elevated in older rats and humans, with greater accumulation occurring in the substantia nigra and striatum compared with the thalamus, globus pallidus, cerebellum, and cortex $(231,298,300)$.

Feedback through redox-sensitive mechanisms may help to limit oxidative damage associated with DA metabolism. For example, oxidative modification of the DA transporter can inhibit activity, limiting uptake, and subsequent metabolism $(2,23)$. Similar to the synthesis of GABA, DA synthesis is also decreased as oxidative stress increases. The decrease in synthesis is mediated by inhibition of tyrosine hydroxylase, the synthesizing enzyme, and rate-limiting step of DA production. Reversible inhibition can occur through disulfide bond formation on cysteines (34). As oxidative stress increases, formation of 3-nitrotyrosine by peroxynitrite may result in an irreversible inhibition of tyrosine hydroxylase (30).

In contrast to DA, low concentrations of norepinephrine can elicit neuroprotective effects for dopaminergic, cholinergic, hippocampal, and cortical neurons in vitro $(61,169$, 170, 276, 278). The mechanism appears to involve decreased 
neuroinflammation, inhibition of microglial NOX, and inhibition of induction of iNOS $(52,131,185)$. In addition, extracellular norepinephrine may exhibit antioxidant properties $(276,278)$. It should be noted that the above studies of neuroprotective effects of norepinephrine have mainly been performed in vitro. The ability of endogenous norepinephrine to protect neurons is also suggested by studies that report lesions of the locus coeruleus or inhibition of norepinephrine synthesis enhances inflammation and oxidative stress induced by stressors $(118,126,130,290)$.

\section{Acetylcholine}

Cholinergic integrity is crucial to cognitive processes that decline with age, including attention and working memory $(58,65,179,238)$. The basal forebrain is a rich source of cholinergic neurons, which may be preferentially lost in Alzheimer's disease. Indeed, this brain region may exhibit increased vulnerability to oxidative stress, with higher levels of peroxides and oxidized GSH (48). In agreement with this idea, cholinergic neurons are highly susceptible to cell death following treatment with oxidized lipids (38). The oxidized lipid, 4-HNE, disrupts coupling of muscarinic cholinergic receptors to phospholipase C-linked GTP-binding proteins (29). The effect likely involves redox signaling since the process is reversed by GSH. A similar decline was observed for activation of metabotropic glutamate receptors and $\mathrm{G} \alpha \mathrm{q} /$ 11 binds 4-HNE suggesting a common mechanism (29).

The loss of cholinergic input may provide two hits on vulnerable brain regions. In addition to loss of information provided by cholinergic input, cholinergic activity is neuroprotective. Under conditions of injury (i.e., ischemia and hemorrhage), cholinergic stimulation, specifically of $\alpha 7$ nicotinic acetylcholine receptors (nAChRs), elicits neuroprotective effects by inhibiting proapoptotic signaling cascades within neurons $(64,138)$ and activating the nuclear factor erythroid 2related factor (Nrf2) pathway in microglia, which reduces ROS and tumor necrosis factor levels via increased heme oxygenase1 expression (206). Nrf2 and its downstream products are crucial in maintaining proper redox homeostasis, and agerelated changes in this pathway contribute to increased vulnerability due to heightened oxidative stress. For example, Nrf2 messenger RNA (mRNA) levels and transcriptional activity decline over the course of aging, resulting in decreased synthesis of GSH (266). Moreover, the decline in function renders neural circuits of middle-aged and aged animals more susceptible to environmental toxins that contribute to neurodegenerative diseases (145). Finally, aging may shift the expression of $\alpha 7 \mathrm{nAChRs}$ on astrocytes and inhibitory interneurons in the hippocampal CA1 region (94), and reduced expression of $\alpha 7$ nAChRs has been reported in the frontal cortex in elderly humans (282). The loss of cholinergic input, $\alpha 7 \mathrm{nAChRs,} \mathrm{and}$ redox-mediated decrease in muscarinic function in the PFC would likely influence cognitive processes (e.g., attention and working memory) that depend on this region.

\section{$K^{+}$channels}

In addition to transmitter systems, an age-related change in redox state is likely to influence physiology by modifying voltage-dependent channels, either directly or through redoxsensitive signaling cascades. The function of several $\mathrm{K}^{+}$ channel classes is redox sensitivity, altering activity with a rise in hydrogen peroxide, or following application of DTT or GSH $(233,234,250,301)$. In particular, a shift in the activity of the $\mathrm{Ca}^{2+}$ and voltage-gated BK channel $(237,271,302)$ or $\mathrm{G}$ protein-coupled inwardly rectifying potassium channels (GIRKs) and M-channels $(97,301)$ could influence cell excitability through an increase in the amplitude of the sAHP or increase the response of inhibitory transmitters. Finally, oxidation of the voltage-gated $\mathrm{K}^{+}$channel subfamily $\mathrm{B}$ member 1 (KCNB1) will increase neuronal vulnerability to apoptosis $(59,291,299)$, suggesting that this mechanism could interact with the increased oxidative stress associated with neurodegenerative diseases.

\section{Interaction of Oxidative Stress with Other Aging Mechanisms}

As discussed in Sources for ROS and RNS in the Brain section, the vulnerability of different cell types, cellular compartments, and brain regions depends on the chemical character of the oxidative stressor, level of ROS production, and expression/activity of antioxidant enzymes. In addition to oxidative stress, aging encompasses many other biochemical, physical, and functional changes. In addition to oxidative stress, mitochondrial dysfunction, $\mathrm{Ca}^{2+}$ dyshomeostasis, inflammation, and disruption of neuroendocrine regulation have been proposed as aging mechanisms and common risk factors for neurodegenerative diseases. It is important to recognize that these risk factors interact and that the vulnerability of different brain regions may be explained by specific risk factors. For example, as discussed in Redox Stress and Senescent Physiology section, redox regulation influences $\mathrm{Ca}^{2+}$ homeostasis through the release of $\mathrm{Ca}^{2+}$ from intracellular stores and modulation of NMDA receptor function. Several recent reviews discuss factors that determine regional vulnerability/susceptibility to $\mathrm{Ca}^{2+}$ dyshomeostasis $(140,288)$ and relate how an oxidized redox state influences $\mathrm{Ca}^{2+}$ homeostasis, which precedes the accumulation of oxidative damage during aging and neurodegenerative diseases $(72,90,102,209)$.

\section{Inflammation}

A persistent low-level increase in serum markers of inflammation is consistently observed during aging and is thought to contribute to age-related diseases $(51,121,255)$, including Alzheimer's disease, and age-related memory deficits $(25,53,62,105,168,190,219,241)$. Proinflammatory cytokines, IL- $1 \beta$, IL- 6 , and TNF- $\alpha$, cross the blood-brain barrier to activate glia and increase ROS production $(12,13,73,109)$. Furthermore, the increase in ROS with age may contribute to this process as ROS activates inflammatory signaling through stress kinases (JNK, p38) and transcription of proinflammatory mediators through NFkappaB $(122,220)$.

Markers of inflammation and oxidative stress vary across brain regions $(16,127,241,246,254,286)$. The mechanisms for differential susceptibility to inflammation are unknown, but may be due to the distribution of microglia or differential expression of receptors for cytokines that cross the bloodbrain barrier $(93,106,148,243)$. The relationship between oxidative stress and markers of neuroinflammation in different brain regions and disruption of specific cognitive processes mediated by these brain regions is complex. Microglial activation may be beneficial or detrimental to neurons. 
Neuroinflammation arises as part of a process to initiate tissue repair and support neurons exposed to oxidative stress (264, 265). Regional differences in the expression of proteins or genes that signify microglial activation (e.g., major histocompatibility complex II antigens) are not necessarily linked to cognitive impairment $(28,127,285)$. In contrast, senescent microglia release of proinflammatory cytokines and chemokines that induce oxidative stress (265) and local elevation of these signaling molecules are linked to impaired cognition (241). Thus, the activity of signaling molecules and level of oxidative stress should be assessed when considering the role of neuroinflammation in brain function.

\section{Neuroendrocrine regulation of brain aging}

Similar to systemic inflammation, aging is associated with an increase in plasma levels of glucocorticoids $(167,180)$. Normally, glucocorticoid receptor (GR) transcriptional activity mediates a reduction in inflammation and an associated reduction in oxidative stress (15). However, the release of high levels of glucocorticoids during behavioral stress can induce an increase in NOX activity, decrease the levels of the reduced form of GSH, and induce oxidative damage $(41,239,248)$. Brain regions that are vulnerable to behavioral stress include the striatum, hippocampus, and PFC (262). Furthermore, under oxidizing conditions, GR activity is decreased due to redox regulation of ligand binding, decreased transport of the receptor into the nucleus, and redox regulation of DNA binding $(201,270)$.

Sex steroids decline with age, and sex steroids interact with brain aging mechanisms. In particular, estrogen has effects on physiology that are diametrically opposite to senescent physiology (84), including the ability to increase NMDA receptor function and decrease the amplitude of the sAHP $(18,142)$. While it is clear that estrogens can reduce oxidative damage, the mechanism is less clear. Estrogens may act to promote antioxidant capacity by regulating antioxidant enzyme activity or through effects on mitochondrial function $(132,135,163$, 184, 297). Finally, there are several estrogen receptors, and effects of estrogen treatments likely reflect age and regional differences in receptor expression $(17,88,113,139)$.

Finally, food restriction is the most reliable method for extending life span, which has led to an extensive body of research on gene mutations linked to insulin and insulin-like growth factor signaling. In general, reduced insulin receptor signaling is associated with increased life span. Normally, insulin induces an increase in hydrogen peroxide, which results in autophosphorylation of the insulin receptor (263). Under these relatively mild oxidative conditions, phosphatases are inhibited through cysteine modifications, while the insulin receptor tyrosine kinase is activated $(72,242)$. With an increase in oxidative stress, S-nitrosylation of the insulindegrading enzyme will inhibit the breakdown of several peptides, including insulin and amyloid (7). Thus, similar to the effects of redox state on synaptic function, an oxidized redox state may be associated with a prolonged on state for insulin receptor signaling (37). In turn, disruption of insulin signaling will disrupt energy homeostasis and could contribute to altered synaptic transmission and neurodegeneration $(69,213,304)$.

\section{Summary}

Redox signaling depends on the reversible modification of redox-sensitive proteins. During aging, a rise in hydrogen peroxide or nitric oxide results in constitutive or prolonged activation of redox signaling and the emergence of senescent physiology linked to impaired cognition. Due to the reversible nature of redox reactions, senescent physiology may be modifiable; however, unchecked, oxidative stress may progress, resulting in increasing levels of highly reactive forms of ROS and RNS and the accumulation of oxidative damage. In turn, oxidative damage may further alter physiological processes and contribute to neurodegeneration. This continuum of functional alterations, from redox signaling to oxidative damage, can be described for several transmitter systems. For each system, senescent physiology may represent the co-opting of transmitter signaling pathways that are normally responsible for feedback regulation of synaptic function. The vulnerability of transmitter systems, neural circuits, and brain regions depends on the chemical character of the oxidative stressor, level of ROS production, and expression/activity of antioxidant enzymes or redox buffering. In addition, the liability of specific systems or circuits is influenced by transmitters that induce ROS production during synaptic activity (e.g., NMDA receptors) or as part of transmitter breakdown (e.g., DA). Finally, vulnerability to oxidative stress will depend on the concentration of reactive metals, function of local astrocytes and microglia, and response to inflammatory or hormonal signals.

\section{Acknowledgments}

Financial support by National Institutes of Aging Grants, R01AG037984, R37AG036800, R01AG049711, and RO1AG052258, and the Evelyn F. McKnight Brain Research Foundation is highly appreciated.

\section{References}

1. Abd El Mohsen MM, Iravani MM, Spencer JP, Rose S, Fahim AT, Motawi TM, Ismail NA, and Jenner P. Ageassociated changes in protein oxidation and proteasome activities in rat brain: Modulation by antioxidants. Biochem Biophys Res Commun 336: 386-391, 2005.

2. Adamczyk A, Kazmierczak A, and Strosznajder JB. Alpha-synuclein and its neurotoxic fragment inhibit dopamine uptake into rat striatal synaptosomes. Relationship to nitric oxide. Neurochem Int 49: 407-412, 2006.

3. Aizenman E, Hartnett KA, and Reynolds IJ. Oxygen free radicals regulate NMDA receptor function via a redox modulatory site. Neuron 5: 841-846, 1990.

4. Aizenman E, Lipton SA, and Loring RH. Selective modulation of NMDA responses by reduction and oxidation. Neuron 2: 1257-1263, 1989.

5. Akaishi T, Nakazawa K, Sato K, Ohno Y, and Ito Y. 4Hydroxynonenal modulates the long-term potentiation induced by L-type $\mathrm{Ca}^{2+}$ channel activation in the rat dentate gyrus in vitro. Neurosci Lett 370: 155-159, 2004.

6. Akaishi T, Nakazawa K, Sato K, Saito H, Ohno Y, and Ito Y. Modulation of voltage-gated $\mathrm{Ca}^{2+}$ current by 4hydroxynonenal in dentate granule cells. Biol Pharm Bull 27: 174-179, 2004.

7. Akhtar MW, Sanz-Blasco S, Dolatabadi N, Parker J, Chon K, Lee MS, Soussou W, McKercher SR, Ambasudhan R, Nakamura T, and Lipton SA. Elevated glucose and oligomeric beta-amyloid disrupt synapses via a common pathway of aberrant protein S-nitrosylation. Nat Commun 7: 10242, 2016. 
8. Aksenova MV, Aksenov MY, Carney JM, and Butterfield DA. Protein oxidation and enzyme activity decline in old brown Norway rats are reduced by dietary restriction. Mech Ageing Dev 100: 157-168, 1998.

9. Alper G, Girgin FK, Ozgonul M, Mentes G, and Ersoz B. MAO inhibitors and oxidant stress in aging brain tissue. Eur Neuropsychopharmacol 9: 247-252, 1999.

10. Amato A, Connolly CN, Moss SJ, and Smart TG. Modulation of neuronal and recombinant GABAA receptors by redox reagents. J Physiol 517 (Pt 1): 35-50, 1999.

11. Armogida M, Spalloni A, Amantea D, Nutini M, Petrelli F, Longone P, Bagetta G, Nistico R, and Mercuri NB. The protective role of catalase against cerebral ischemia in vitro and in vivo. Int J Immunopathol Pharmacol 24: 735-747, 2011.

12. Banks WA, Kastin AJ, and Gutierrez EG. Penetration of interleukin-6 across the murine blood-brain barrier. $\mathrm{Neu}$ rosci Lett 179: 53-56, 1994.

13. Banks WA, Ortiz L, Plotkin SR, and Kastin AJ. Human interleukin (IL) 1 alpha, murine IL-1 alpha and murine IL1 beta are transported from blood to brain in the mouse by a shared saturable mechanism. J Pharmacol Exp Ther 259: 988-996, 1991.

14. Barnes CA. Long-term potentiation and the ageing brain. Philos Trans R Soc Lond B Biol Sci 358: 765-772, 2003.

15. Barnes PJ. Mechanisms and resistance in glucocorticoid control of inflammation. J Steroid Biochem Mol Biol 120: 76-85, 2010.

16. Barrientos RM, Frank MG, Hein AM, Higgins EA, Watkins LR, Rudy JW, and Maier SF. Time course of hippocampal IL-1 beta and memory consolidation impairments in aging rats following peripheral infection. Brain Behav Immun 23: 46-54, 2009.

17. Bean LA, Ianov L, and Foster TC. Estrogen receptors, the hippocampus, and memory. Neuroscientist 20: 534-545, 2014.

18. Bean LA, Kumar A, Rani A, Guidi M, Rosario AM, Cruz PE, Golde TE, and Foster TC. Re-opening the critical window for estrogen therapy. J Neurosci 35: 16077 16093, 2015.

19. Behrens MM, Ali SS, Dao DN, Lucero J, Shekhtman G, Quick KL, and Dugan LL. Ketamine-induced loss of phenotype of fast-spiking interneurons is mediated by NADPH-oxidase. Science 318: 1645-1647, 2007.

20. Ben-Yoseph O, Boxer PA, and Ross BD. Assessment of the role of the glutathione and pentose phosphate pathways in the protection of primary cerebrocortical cultures from oxidative stress. J Neurochem 66: 2329-2337, 1996.

21. Benkovic SA, and Connor JR. Ferritin, transferrin, and iron in selected regions of the adult and aged rat brain. J Comp Neurol 338: 97-113, 1993.

22. Berlett BS, and Stadtman ER. Protein oxidation in aging, disease, and oxidative stress. J Biol Chem 272: $20313-$ 20316, 1997.

23. Berman SB, Zigmond MJ, and Hastings TG. Modification of dopamine transporter function: Effect of reactive oxygen species and dopamine. J Neurochem 67: 593-600, 1996.

24. Bernard CL, Hirsch JC, Khazipov R, Ben-Ari Y, and Gozlan H. Redox modulation of synaptic responses and plasticity in rat CA1 hippocampal neurons. Exp Brain Res 113: 343-352, 1997.

25. Bettcher BM, Wilheim R, Rigby T, Green R, Miller JW, Racine CA, Yaffe K, Miller BL, and Kramer JH. C- reactive protein is related to memory and medial temporal brain volume in older adults. Brain Behav Immun 26: 103-108, 2012.

26. Bigelow DJ, and Squier TC. Redox modulation of cellular signaling and metabolism through reversible oxidation of methionine sensors in calcium regulatory proteins. Biochim Biophys Acta 1703: 121-134, 2005.

27. Bilkei-Gorzo A. Genetic mouse models of brain ageing and Alzheimer's disease. Pharmacol Ther 142: 244-257, 2014.

28. Blalock EM, Chen KC, Sharrow K, Herman JP, Porter NM, Foster TC, and Landfield PW. Gene microarrays in hippocampal aging: Statistical profiling identifies novel processes correlated with cognitive impairment. $\mathrm{J} \mathrm{Neu}$ rosci 23: 3807-3819, 2003.

29. Blanc EM, Kelly JF, Mark RJ, Waeg G, and Mattson MP. 4-Hydroxynonenal, an aldehydic product of lipid peroxidation, impairs signal transduction associated with muscarinic acetylcholine and metabotropic glutamate receptors: Possible action on $\mathrm{G}$ alpha(q/11). J Neurochem 69: 570-580, 1997.

30. Blanchard-Fillion B, Souza JM, Friel T, Jiang GC, Vrana K, Sharov V, Barron L, Schoneich C, Quijano C, Alvarez B, Radi R, Przedborski S, Fernando GS, Horwitz J, and Ischiropoulos $\mathrm{H}$. Nitration and inactivation of tyrosine hydroxylase by peroxynitrite. J Biol Chem 276: 4601746023, 2001.

31. Bodhinathan K, Kumar A, Foster TC. Intracellular redox state alters NMDA receptor response during aging through $\mathrm{Ca}^{2+} /$ calmodulin-dependent protein kinase II. J Neurosci 30: 1914-1924, 2010.

32. Bodhinathan K, Kumar A, and Foster TC. Redox sensitive calcium stores underlie enhanced after hyperpolarization of aged neurons: Role for ryanodine receptor mediated calcium signaling. J Neurophysiol 104: 2586-2593, 2010.

33. Bondy SC, and Lee DK. Oxidative stress induced by glutamate receptor agonists. Brain Res 610: 229-233, 1993.

34. Borges CR, Geddes T, Watson JT, and Kuhn DM. Dopamine biosynthesis is regulated by S-glutathionylation. Potential mechanism of tyrosine hydroxylast inhibition during oxidative stress. J Biol Chem 277: 48295-48302, 2002.

35. Bradley SA, and Steinert JR. Nitric oxide-mediated posttranslational modifications: impacts at the synapse. Oxid Med Cell Longev 2016: 5681036, 2016.

36. Brennan AM, Suh SW, Won SJ, Narasimhan P, Kauppinen TM, Lee H, Edling Y, Chan PH, and Swanson RA. NADPH oxidase is the primary source of superoxide induced by NMDA receptor activation. Nat Neurosci 12: 857-863, 2009.

37. Brewer GJ. Epigenetic oxidative redox shift (EORS) theory of aging unifies the free radical and insulin signaling theories. Exp Gerontol 45: 173-179, 2010.

38. Bruce-Keller AJ, Li YJ, Lovell MA, Kraemer PJ, Gary DS, Brown RR, Markesbery WR, and Mattson MP. 4Hydroxynonenal, a product of lipid peroxidation, damages cholinergic neurons and impairs visuospatial memory in rats. J Neuropathol Exp Neurol 57: 257-267, 1998.

39. Burke SN, and Barnes CA. Neural plasticity in the ageing brain. Nat Rev Neurosci 7: 30-40, 2006.

40. Butterfield DA, and Sultana R. Redox proteomics identification of oxidatively modified brain proteins in Alzheimer's disease and mild cognitive impairment: Insights 
into the progression of this dementing disorder. $J$ Alzheimers Dis 12: 61-72, 2007.

41. Caccamo A, Medina DX, and Oddo S. Glucocorticoids exacerbate cognitive deficits in TDP-25 transgenic mice via a glutathione-mediated mechanism: Implications for aging, stress and TDP-43 proteinopathies. J Neurosci 33: 906-913, 2013.

42. Cai SQ, and Sesti F. Oxidation of a potassium channel causes progressive sensory function loss during aging. Nat Neurosci 12: 611-617, 2009.

43. Cai Z, and Yan LJ. Protein oxidative modifications: beneficial roles in disease and health. $J$ Biochem Pharmacol Res 1: 15-26, 2013.

44. Cakatay U, Telci A, Kayali R, Tekeli F, Akcay T, and Sivas A. Relation of oxidative protein damage and nitrotyrosine levels in the aging rat brain. Exp Gerontol 36: 221-229, 2001.

45. Calabrese V, Bates TE, and Stella AM. NO synthase and NO-dependent signal pathways in brain aging and neurodegenerative disorders: The role of oxidant/antioxidant balance. Neurochem Res 25: 1315-1341, 2000.

46. Calabrese V, Boyd-Kimball D, Scapagnini G, and Butterfield DA. Nitric oxide and cellular stress response in brain aging and neurodegenerative disorders: The role of vitagenes. In Vivo 18: 245-267, 2004.

47. Calabrese V, Scapagnini G, Ravagna A, Colombrita C, Spadaro F, Butterfield DA, and Giuffrida Stella AM. Increased expression of heat shock proteins in rat brain during aging: Relationship with mitochondrial function and glutathione redox state. Mech Ageing Dev 125: 325-335, 2004.

48. Calabrese V, Scapagnini G, Ravagna A, Fariello RG, Giuffrida Stella AM, and Abraham NG. Regional distribution of heme oxygenase, HSP70, and glutathione in brain: Relevance for endogenous oxidant/antioxidant balance and stress tolerance. J Neurosci Res 68: 65-75, 2002.

49. Carai MA, Vacca G, Serra S, Colombo G, Froestl W, and Gessa GL. Suppression of GABA(B) receptor function in vivo by disulfide reducing agent, DL-dithiothreitol (DTT). Psychopharmacology (Berl) 174: 283-290, 2004.

50. Castegna A, Aksenov M, Aksenova M, Thongboonkerd V, Klein JB, Pierce WM, Booze R, Markesbery WR, and Butterfield DA. Proteomic identification of oxidatively modified proteins in Alzheimer's disease brain. Part I: Creatine kinase BB, glutamine synthase, and ubiquitin carboxy-terminal hydrolase L-1. Free Radic Biol Med 33: 562-571, 2002.

51. Cevenini E, Monti D, and Franceschi C. Inflamm-ageing. Curr Opin Clin Nutr Metab Care 16: 14-20, 2013.

52. Chang JY, and Liu LZ. Catecholamines inhibit microglial nitric oxide production. Brain Res Bull 52: 525-530, 2000.

53. Chen J, Buchanan JB, Sparkman NL, Godbout JP, Freund GG, and Johnson RW. Neuroinflammation and disruption in working memory in aged mice after acute stimulation of the peripheral innate immune system. Brain Behav Immun 22: 301-311, 2008.

54. Chen SH, Oyarzabal EA, and Hong JS. Critical role of the Mac1/NOX2 pathway in mediating reactive microgliosisgenerated chronic neuroinflammation and progressive neurodegeneration. Curr Opin Pharmacol 26: 54-60, 2016.

55. Cheret C, Gervais A, Lelli A, Colin C, Amar L, Ravassard $\mathrm{P}$, Mallet J, Cumano A, Krause $\mathrm{KH}$, and Mallat $\mathrm{M}$. Neurotoxic activation of microglia is promoted by a nox 1dependent NADPH oxidase. J Neurosci 28: 12039-12051, 2008.
56. Choi DW. Excitotoxic cell death. J Neurobiol 23: 12611276, 1992.

57. Chu XP, Close N, Saugstad JA, and Xiong ZG. ASIC1aspecific modulation of acid-sensing ion channels in mouse cortical neurons by redox reagents. J Neurosci 26: 5329 5339, 2006.

58. Chudasama Y, Dalley JW, Nathwani F, Bouger P, and Robbins TW. Cholinergic modulation of visual attention and working memory: Dissociable effects of basal forebrain 192-IgG-saporin lesions and intraprefrontal infusions of scopolamine. Learn Mem 11: 78-86, 2004.

59. Cotella D, Hernandez-Enriquez B, Wu X, Li R, Pan Z, Leveille J, Link CD, Oddo S, and Sesti F. Toxic role of $\mathrm{K}+$ channel oxidation in mammalian brain. $J$ Neurosci 32: 4133-4144, 2012.

60. Coultrap SJ, and Bayer KU. Nitric oxide induces $\mathrm{Ca}^{2+}$ independent activity of the $\mathrm{Ca}^{2+} /$ calmodulin-dependent protein kinase II (CaMKII). J Biol Chem 289: 1945819465, 2014.

61. Counts SE, and Mufson EJ. Noradrenaline activation of neurotrophic pathways protects against neuronal amyloid toxicity. J Neurochem 113: 649-660, 2010.

62. Craft S, Foster TC, Landfield PW, Maier SF, Resnick SM, and Yaffe K. Session III: Mechanisms of age-related cognitive change and targets for intervention: Inflammatory, oxidative, and metabolic processes. $J$ Gerontol A Biol Sci Med Sci 67: 754-759, 2012.

63. Crivello NA, Rosenberg IH, Shukitt-Hale B, Bielinski D, Dallal GE, and Joseph JA. Aging modifies brain region-specific vulnerability to experimental oxidative stress induced by low dose hydrogen peroxide. Age (Dordr) 29: 191-203, 2007.

64. Crowder RJ, and Freeman RS. Glycogen synthase kinase3 beta activity is critical for neuronal death caused by inhibiting phosphatidylinositol 3-kinase or Akt but not for death caused by nerve growth factor withdrawal. $J$ Biol Chem 275: 34266-34271, 2000.

65. Croxson PL, Kyriazis DA, and Baxter MG. Cholinergic modulation of a specific memory function of prefrontal cortex. Nat Neurosci 14: 1510-1512, 2011.

66. Cui L, Hofer T, Rani A, Leeuwenburgh C, and Foster TC. Comparison of lifelong and late life exercise on oxidative stress in the cerebellum. Neurobiol Aging 30: 903-909, 2009.

67. Dai DF, Santana LF, Vermulst M, Tomazela DM, Emond MJ, MacCoss MJ, Gollahon K, Martin GM, Loeb LA, Ladiges WC, and Rabinovitch PS. Overexpression of catalase targeted to mitochondria attenuates murine cardiac aging. Circulation 119: 2789-2797, 2009.

68. Davies SM, Poljak A, Duncan MW, Smythe GA, and Murphy MP. Measurements of protein carbonyls, orthoand meta-tyrosine and oxidative phosphorylation complex activity in mitochondria from young and old rats. Free Radic Biol Med 31: 181-190, 2001.

69. de la Monte SM, and Wands JR. Review of insulin and insulin-like growth factor expression, signaling, and malfunction in the central nervous system: Relevance to Alzheimer's disease. J Alzheimers Dis 7: 45-61, 2005.

70. Dejanovic B, and Schwarz G. Neuronal nitric oxide synthase-dependent S-nitrosylation of gephyrin regulates gephyrin clustering at GABAergic synapses. J Neurosci 34: 7763-7768, 2014.

71. deToledo-Morrell L, Geinisman Y, and Morrell F. Agedependent alterations in hippocampal synaptic plasticity: Relation to memory disorders. Neurobiol Aging 9: 581590, 1988. 
72. Droge W, and Schipper HM. Oxidative stress and aberrant signaling in aging and cognitive decline. Aging Cell 6: 361-370, 2007.

73. Dugan LL, Ali SS, Shekhtman G, Roberts AJ, Lucero J, Quick KL, and Behrens MM. IL-6 mediated degeneration of forebrain GABAergic interneurons and cognitive impairment in aged mice through activation of neuronal NADPH oxidase. PLoS One 4: e5518, 2009.

74. Dumont M, Wille E, Stack C, Calingasan NY, Beal MF, and Lin MT. Reduction of oxidative stress, amyloid deposition, and memory deficit by manganese superoxide dismutase overexpression in a transgenic mouse model of Alzheimer's disease. FASEB J 23: 2459-2466, 2009.

75. Emir UE, Raatz S, McPherson S, Hodges JS, Torkelson C, Tawfik P, White T, and Terpstra M. Noninvasive quantification of ascorbate and glutathione concentration in the elderly human brain. NMR Biomed 24: 888-894, 2011.

76. Fazeli G, Oli RG, Schupp N, and Stopper H. The role of the dopamine transporter in dopamine-induced DNA damage. Brain Pathol 21: 237-248, 2011.

77. Febo M, and Foster TC. Preclinical magnetic resonance imaging and spectroscopy studies of memory, aging, and cognitive decline. Front Aging Neurosci 8: 158, 2016.

78. Ferrini M, Wang C, Swerdloff RS, Sinha Hikim AP, Rajfer J, and Gonzalez-Cadavid NF. Aging-related increased expression of inducible nitric oxide synthase and cytotoxicity markers in rat hypothalamic regions associated with male reproductive function. Neuroendocrinology 74: 1-11, 2001.

79. Floyd RA, and Hensley K. Oxidative stress in brain aging. Implications for therapeutics of neurodegenerative diseases. Neurobiol Aging 23: 795-807, 2002.

80. Foley TD, Katchur KM, and Gillespie PF. Disulfide stress targets modulators of excitotoxicity in otherwise healthy brains. Neurochem Res 41: 2763-2770, 2016.

81. Forster MJ, Dubey A, Dawson KM, Stutts WA, Lal H, and Sohal RS. Age-related losses of cognitive function and motor skills in mice are associated with oxidative protein damage in the brain. Proc Natl Acad Sci U S A 93: 47654769, 1996.

82. Foster TC. Involvement of hippocampal synaptic plasticity in age-related memory decline. Brain Res Brain Res Rev 30: 236-249, 1999.

83. Foster TC. Regulation of synaptic plasticity in memory and memory decline with aging. Prog Brain Res 138: 283-303, 2002.

84. Foster TC. Interaction of rapid signal transduction cascades and gene expression in mediating estrogen effects on memory over the life span. Front Neuroendocrinol 26: 51-64, 2005.

85. Foster TC. Biological markers of age-related memory deficits: Treatment of senescent physiology. CNS Drugs 20: 153-166, 2006.

86. Foster TC. Calcium homeostasis and modulation of synaptic plasticity in the aged brain. Aging Cell 6: 319-325, 2007.

87. Foster TC. Dissecting the age-related decline on spatial learning and memory tasks in rodent models: N-methyl-Daspartate receptors and voltage-dependent $\mathrm{Ca}^{2+}$ channels in senescent synaptic plasticity. Prog Neurobiol 96: 283303, 2012.

88. Foster TC. Role of estrogen receptor alpha and beta expression and signaling on cognitive function during aging. Hippocampus 22: 656-669, 2012.
89. Foster TC, and Kumar A. Calcium dysregulation in the aging brain. Neuroscientist 8: 297-301, 2002.

90. Foster TC, Kyritsopoulos C, and Kumar A. Central role for NMDA receptors in redox mediated impairment of synaptic function during aging and Alzheimer's disease. Behav Brain Res 322: 223-232, 2016.

91. Foster TC, and Norris CM. Age-associated changes in $\mathrm{Ca}(2+)$-dependent processes: Relation to hippocampal synaptic plasticity. Hippocampus 7: 602-612, 1997.

92. Foster TC, Sharrow KM, Masse JR, Norris CM, and Kumar A. Calcineurin links $\mathrm{Ca}^{2+}$ dysregulation with brain aging. J Neurosci 21: 4066-4073, 2001.

93. Gadient RA, and Otten U. Expression of interleukin-6 (IL6) and interleukin-6 receptor (IL-6R) mRNAs in rat brain during postnatal development. Brain Res 637: 10-14, 1994.

94. Gahring LC, Persiyanov K, Dunn D, Weiss R, Meyer EL, and Rogers SW. Mouse strain-specific nicotinic acetylcholine receptor expression by inhibitory interneurons and astrocytes in the dorsal hippocampus. J Comp Neurol 468: 334-346, 2004.

95. Gahtan E, Auerbach JM, Groner Y, and Segal M. Reversible impairment of long-term potentiation in transgenic Cu/Zn-SOD mice. Eur J Neurosci 10: 538-544, 1998.

96. Galvez T, Parmentier ML, Joly C, Malitschek B, Kaupmann K, Kuhn R, Bittiger H, Froestl W, Bettler B, and Pin JP. Mutagenesis and modeling of the GABAB receptor extracellular domain support a venus flytrap mechanism for ligand binding. J Biol Chem 274: 13362-13369, 1999.

97. Gamper N, Zaika O, Li Y, Martin P, Hernandez CC, Perez MR, Wang AY, Jaffe DB, and Shapiro MS. Oxidative modification of M-type $\mathrm{K}(+)$ channels as a mechanism of cytoprotective neuronal silencing. EMBO J 25: 4996-5004, 2006.

98. Gant JC, Sama MM, Landfield PW, and Thibault O. Early and simultaneous emergence of multiple hippocampal biomarkers of aging is mediated by $\mathrm{Ca}^{2+}$-induced $\mathrm{Ca}^{2+}$ release. J Neurosci 26: 3482-3490, 2006.

99. Garthwaite J. Glutamate, nitric oxide and cell-cell signalling in the nervous system. Trends Neurosci 14: 60-67, 1991.

100. Gasulla J, and Calvo DJ. Enhancement of tonic and phasic GABAergic currents following nitric oxide synthase inhibition in hippocampal CA1 pyramidal neurons. Neurosci Lett 590: 29-34, 2015.

101. Gemma C, Vila J, Bachstetter A, and Bickford PC. Oxidative stress and the aging brain: From theory to prevention. In: Brain Aging: Models, Methods, and Mechanisms, edited by Riddle DR. Boca Raton, FL: CRS Press, Taylor \& Francis Group, 2007, pp. 353-374.

102. Ghosh D, LeVault KR, Barnett AJ, and Brewer GJ. A reversible early oxidized redox state that precedes macromolecular ROS damage in aging nontransgenic and 3xTgAD mouse neurons. J Neurosci 32: 5821-5832, 2012.

103. Gilbert HF. Molecular and cellular aspects of thioldisulfide exchange. Adv Enzymol Relat Areas Mol Biol 63: 69-172, 1990.

104. Gilmer LK, Ansari MA, Roberts KN, and Scheff SW. Age-related changes in mitochondrial respiration and oxidative damage in the cerebral cortex of the Fischer 344 rat. Mech Ageing Dev 131: 133-143, 2010.

105. Gimeno D, Marmot MG, and Singh-Manoux A. Inflammatory markers and cognitive function in middleaged adults: The Whitehall II study. Psychoneuroendocrinology 33: 1322-1334, 2008.

106. Grabert K, Michoel T, Karavolos MH, Clohisey S, Baillie JK, Stevens MP, Freeman TC, Summers KM, and McColl 
BW. Microglial brain region-dependent diversity and selective regional sensitivities to aging. Nat Neurosci 19: 504-516, 2016.

107. Green SP, Cairns B, Rae J, Errett-Baroncini C, Hongo JA, Erickson RW, and Curnutte JT. Induction of gp91-phox, a component of the phagocyte NADPH oxidase, in microglial cells during central nervous system inflammation. $J$ Cereb Blood Flow Metab 21: 374-384, 2001.

108. Guidi M, Kumar A, and Foster TC. Impaired attention and synaptic senescence of the prefrontal cortex involves redox regulation of NMDA receptors. J Neurosci 35: 39663977, 2015.

109. Gutierrez EG, Banks WA, and Kastin AJ. Murine tumor necrosis factor alpha is transported from blood to brain in the mouse. J Neuroimmunol 47: 169-176, 1993.

110. Hall DJ, Han SH, Chepetan A, Inui EG, Rogers M, and Dugan LL. Dynamic optical imaging of metabolic and NADPH oxidase-derived superoxide in live mouse brain using fluorescence lifetime unmixing. J Cereb Blood Flow Metab 32: 23-32, 2012.

111. Halliwell B. Reactive oxygen species and the central nervous system. J Neurochem 59: 1609-1623, 1992.

112. Hamilton ML, Van Remmen H, Drake JA, Yang H, Guo ZM, Kewitt K, Walter CA, and Richardson A. Does oxidative damage to DNA increase with age? Proc Natl Acad Sci U S A 98: 10469-10474, 2001.

113. Han X, Aenlle KK, Bean LA, Rani A, Semple-Rowland SL, Kumar A, and Foster TC. Role of estrogen receptor alpha and beta in preserving hippocampal function during aging. J Neurosci 33: 2671-2683, 2013.

114. Handy DE, Lubos E, Yang Y, Galbraith JD, Kelly N, Zhang YY, Leopold JA, and Loscalzo J. Glutathione peroxidase-1 regulates mitochondrial function to modulate redox-dependent cellular responses. J Biol Chem 284: 11913-11921, 2009.

115. Harman D. The biologic clock: The mitochondria? J Am Geriatr Soc 20: 145-147, 1972.

116. Hastings TG, Lewis DA, and Zigmond MJ. Role of oxidation in the neurotoxic effects of intrastriatal dopamine injections. Proc Natl Acad Sci U S A 93: 1956-1961, 1996.

117. Haxaire C, Turpin FR, Potier B, Kervern M, Sinet PM, Barbanel G, Mothet JP, Dutar P, and Billard JM. Reversal of age-related oxidative stress prevents hippocampal synaptic plasticity deficits by protecting D-serinedependent NMDA receptor activation. Aging Cell 11: 336-344, 2012.

118. Heneka MT, Ramanathan M, Jacobs AH, DumitrescuOzimek L, Bilkei-Gorzo A, Debeir T, Sastre M, Galldiks N, Zimmer A, Hoehn M, Heiss WD, Klockgether T, and Staufenbiel M. Locus ceruleus degeneration promotes Alzheimer pathogenesis in amyloid precursor protein 23 transgenic mice. J Neurosci 26: 1343-1354, 2006.

119. Hollensworth SB, Shen C, Sim JE, Spitz DR, Wilson GL, and LeDoux SP. Glial cell type-specific responses to menadione-induced oxidative stress. Free Radic Biol Med 28: 1161-1174, 2000.

120. Homayoun $\mathrm{H}$, and Moghaddam B. NMDA receptor hypofunction produces opposite effects on prefrontal cortex interneurons and pyramidal neurons. J Neurosci 27: 11496-11500, 2007.

121. Howcroft TK, Campisi J, Louis GB, Smith MT, Wise B, Wyss-Coray T, Augustine AD, McElhaney JE, Kohanski $\mathrm{R}$, and Sierra $\mathrm{F}$. The role of inflammation in age-related disease. Aging (Albany NY) 5: 84-93, 2013.
122. Hsieh HL, and Yang CM. Role of redox signaling in neuroinflammation and neurodegenerative diseases. Biomed Res Int 2013: 484613, 2013.

123. Hu D, Cao P, Thiels E, Chu CT, Wu GY, Oury TD, and Klann E. Hippocampal long-term potentiation, memory, and longevity in mice that overexpress mitochondrial superoxide dismutase. Neurobiol Learn Mem 87: 372-384, 2007.

124. Huang KP, Huang FL, Li J, Schuck P, and McPhie P. Calcium-sensitive interaction between calmodulin and modified forms of rat brain neurogranin/RC3. Biochemistry 39: 7291-7299, 2000.

125. Huang Y, Man HY, Sekine-Aizawa Y, Han Y, Juluri K, Luo H, Cheah J, Lowenstein C, Huganir RL, and Snyder SH. S-nitrosylation of N-ethylmaleimide sensitive factor mediates surface expression of AMPA receptors. Neuron 46: 533-540, 2005.

126. Hurko O, Boudonck K, Gonzales C, Hughes ZA, Jacobsen JS, Reinhart PH, and Crowther D. Ablation of the locus coeruleus increases oxidative stress in tg-2576 transgenic but not wild-type mice. Int J Alzheimers Dis 2010: 864625, 2010.

127. Ianov L, Rani A, Beas BS, Kumar A, and Foster TC. Transcription profile of aging and cognition-related genes in the medial prefrontal cortex. Front Aging Neurosci 8: 113, 2016.

128. Imhoff BR, and Hansen JM. Extracellular redox status regulates Nrf2 activation through mitochondrial reactive oxygen species. Biochem J 424: 491-500, 2009.

129. Janaky R, Varga V, Oja SS, and Saransaari P. Release of $[3 \mathrm{H}] \mathrm{GABA}$ evoked by glutamate agonists from hippocampal slices: Effects of dithiothreitol and glutathione. Neurochem Int 24: 575-582, 1994.

130. Jardanhazi-Kurutz D, Kummer MP, Terwel D, Vogel K, Thiele A, and Heneka MT. Distinct adrenergic system changes and neuroinflammation in response to induced locus ceruleus degeneration in APP/PS1 transgenic mice. Neuroscience 176: 396-407, 2011.

131. Jiang L, Chen SH, Chu CH, Wang SJ, Oyarzabal E, Wilson B, Sanders V, Xie K, Wang Q, and Hong JS. A novel role of microglial NADPH oxidase in mediating extra-synaptic function of norepinephrine in regulating brain immune homeostasis. Glia 63: 1057-1072, 2015.

132. Jones TT, and Brewer GJ. Critical age-related loss of cofactors of neuron cytochrome $\mathrm{C}$ oxidase reversed by estrogen. Exp Neurol 215: 212-219, 2009.

133. Jossan SS, Gillberg PG, d'Argy R, Aquilonius SM, Langstrom B, Halldin C, and Oreland L. Quantitative localization of human brain monoamine oxidase $\mathrm{B}$ by large section autoradiography using L-[3H]deprenyl. Brain Res 547: 69-76, 1991.

134. Kamsler A, and Segal M. Paradoxical actions of hydrogen peroxide on long-term potentiation in transgenic superoxide dismutase-1 mice. J Neurosci 23: 10359-10367, 2003.

135. Kiray M, Uysal N, Sonmez A, Acikgoz O, and Gonenc S. Positive effects of deprenyl and estradiol on spatial memory and oxidant stress in aged female rat brains. Neurosci Lett 354: 225-228, 2004.

136. Kishida KT, and Klann E. Sources and targets of reactive oxygen species in synaptic plasticity and memory. Antioxid Redox Signal 9: 233-244, 2007.

137. Knoferle J, Koch JC, Ostendorf T, Michel U, Planchamp V, Vutova P, Tonges L, Stadelmann C, Bruck W, Bahr M, 
and Lingor P. Mechanisms of acute axonal degeneration in the optic nerve in vivo. Proc Natl Acad Sci U S A 107: 6064-6069, 2010.

138. Krafft PR, Altay O, Rolland WB, Duris K, Lekic T, Tang $\mathrm{J}$, and Zhang $\mathrm{JH}$. alpha7 nicotinic acetylcholine receptor agonism confers neuroprotection through GSK-3beta inhibition in a mouse model of intracerebral hemorrhage. Stroke 43: 844-850, 2012.

139. Kumar A, Bean LA, Rani A, Jackson T, and Foster TC. Contribution of estrogen receptor subtypes, ERalpha, ERbeta, and GPER1 in rapid estradiol-mediated enhancement of hippocampal synaptic transmission in mice. Hippocampus 25: 1556-1566, 2015.

140. Kumar A, Bodhinathan K, and Foster TC. Susceptibility to calcium dysregulation during brain aging. Front Aging Neurosci 1: 2, 2009.

141. Kumar A, and Foster T. Environmental enrichment decreases the afterhyperpolarization in senescent rats. Brain Res 1130: 103-107, 2007.

142. Kumar A, and Foster TC. 17Beta-estradiol benzoate decreases the AHP amplitude in CA1 pyramidal neurons. $J$ Neurophysiol 88: 621-626, 2002.

143. Kumar A, and Foster TC. Enhanced long-term potentiation during aging is masked by processes involving intracellular calcium stores. J Neurophysiol 91: 2437-2444, 2004.

144. Kumar A, and Foster TC. Linking redox regulation of NMDAR synaptic function to cognitive decline during aging. J Neurosci 33: 15710-15715, 2013.

145. L'Episcopo F, Tirolo C, Testa N, Caniglia S, Morale MC, Impagnatiello F, Pluchino S, and Marchetti B. Aginginduced Nrf2-ARE pathway disruption in the subventricular zone drives neurogenic impairment in parkinsonian mice via $\mathrm{PI} 3 \mathrm{~K}-\mathrm{Wnt} /$ beta-catenin dysregulation. $J$ Neurosci 33: 1462-1485, 2013.

146. Lambeth JD. NOX enzymes and the biology of reactive oxygen. Nat Rev Immunol 4: 181-189, 2004.

147. Landfield PW, and Pitler TA. Prolonged $\mathrm{Ca}^{2+}$-dependent afterhyperpolarizations in hippocampal neurons of aged rats. Science 226: 1089-1092, 1984.

148. Lawson LJ, Perry VH, Dri P, and Gordon S. Heterogeneity in the distribution and morphology of microglia in the normal adult mouse brain. Neuroscience 39: 151-170, 1990.

149. LeDoux SP, Druzhyna NM, Hollensworth SB, Harrison JF, and Wilson GL. Mitochondrial DNA repair: A critical player in the response of cells of the CNS to genotoxic insults. Neuroscience 145: 1249-1259, 2007.

150. Lee HP, Pancholi N, Esposito L, Previll LA, Wang X, Zhu $\mathrm{X}$, Smith MA, and Lee HG. Early induction of oxidative stress in mouse model of Alzheimer disease with reduced mitochondrial superoxide dismutase activity. PLoS One 7: e28033, 2012.

151. Lee HY, Choi CS, Birkenfeld AL, Alves TC, Jornayvaz FR, Jurczak MJ, Zhang D, Woo DK, Shadel GS, Ladiges W, Rabinovitch PS, Santos JH, Petersen KF, Samuel VT, and Shulman GI. Targeted expression of catalase to mitochondria prevents age-associated reductions in mitochondrial function and insulin resistance. Cell Metab 12: 668-674, 2010.

152. Lee WH, Kumar A, Rani A, and Foster TC. Role of antioxidant enzymes in redox regulation of N-methyl-Daspartate receptor function and memory in middle-aged rats. Neurobiol Aging 35: 1459-1468, 2014.
153. Lee WH, Kumar A, Rani A, Herrera J, Xu J, Someya S, and Foster TC. Influence of viral vector-mediated delivery of superoxide dismutase and catalase to the hippocampus on spatial learning and memory during aging. Antioxid Redox Signal 16: 339-350, 2012.

154. Leeuwenburgh C, Wagner P, Holloszy JO, Sohal RS, and Heinecke JW. Caloric restriction attenuates dityrosine cross-linking of cardiac and skeletal muscle proteins in aging mice. Arch Biochem Biophys 346: 74-80, 1997.

155. Lei XG, Zhu JH, Cheng WH, Bao Y, Ho YS, Reddi AR, Holmgren A, and Arner ES. Paradoxical roles of antioxidant enzymes: Basic mechanisms and health implications. Physiol Rev 96: 307-364, 2016.

156. Levin ED, Brady TC, Hochrein EC, Oury TD, Jonsson LM, Marklund SL, and Crapo JD. Molecular manipulations of extracellular superoxide dismutase: Functional importance for learning. Behav Genet 28: 381-390, 1998.

157. Levin ED, Christopher NC, Lateef S, Elamir BM, Patel M, Liang LP, and Crapo JD. Extracellular superoxide dismutase overexpression protects against aging-induced cognitive impairment in mice. Behav Genet 32: 119-125, 2002.

158. Liddell JR, Robinson SR, Dringen R, and Bishop GM. Astrocytes retain their antioxidant capacity into advanced old age. Glia 58: 1500-1509, 2010.

159. Lipton SA, Choi YB, Pan ZH, Lei SZ, Chen HS, Sucher NJ, Loscalzo J, Singel DJ, and Stamler JS. A redox-based mechanism for the neuroprotective and neurodestructive effects of nitric oxide and related nitroso-compounds. Nature 364: 626-632, 1993.

160. Lipton SA, Choi YB, Takahashi H, Zhang D, Li W, Godzik A, and Bankston LA. Cysteine regulation of protein function-As exemplified by NMDA-receptor modulation. Trends Neurosci 25: 474-480, 2002.

161. Lisman JE, Coyle JT, Green RW, Javitt DC, Benes FM, Heckers S, and Grace AA. Circuit-based framework for understanding neurotransmitter and risk gene interactions in schizophrenia. Trends Neurosci 31: 234-242, 2008.

162. Liu J, Head E, Gharib AM, Yuan W, Ingersoll RT, Hagen TM, Cotman CW, and Ames BN. Memory loss in old rats is associated with brain mitochondrial decay and RNA/ DNA oxidation: Partial reversal by feeding acetyl-Lcarnitine and/or R-alpha -lipoic acid. Proc Natl Acad Sci U S A 99: 2356-2361, 2002.

163. Lopez-Grueso R, Gambini J, Abdelaziz KM, Monleon D, Diaz A, El Alami M, Bonet-Costa V, Borras C, and Vina J. Early, but not late onset estrogen replacement therapy prevents oxidative stress and metabolic alterations caused by ovariectomy. Antioxid Redox Signal 20: 236-246, 2014.

164. Lu C, Chan SL, Fu W, and Mattson MP. The lipid peroxidation product 4-hydroxynonenal facilitates opening of voltage-dependent $\mathrm{Ca}^{2+}$ channels in neurons by increasing protein tyrosine phosphorylation. J Biol Chem 277: 24368-24375, 2002.

165. Lu C, Chan SL, Haughey N, Lee WT, and Mattson MP. Selective and biphasic effect of the membrane lipid peroxidation product 4-hydroxy-2,3-nonenal on N-methyl-Daspartate channels. J Neurochem 78: 577-589, 2001.

166. Luo Y, and Roth GS. The roles of dopamine oxidative stress and dopamine receptor signaling in aging and agerelated neurodegeneration. Antioxid Redox Signal 2: 449460, 2000.

167. Lupien SJ, de Leon M, de Santi S, Convit A, Tarshish C, Nair NP, Thakur M, McEwen BS, Hauger RL, and Meaney MJ. Cortisol levels during human aging predict 
hippocampal atrophy and memory deficits. Nat Neurosci 1: 69-73, 1998.

168. Macchi B, Marino-Merlo F, Frezza C, Cuzzocrea S, and Mastino A. Inflammation and programmed cell death in Alzheimer's disease: Comparison of the central nervous system and peripheral blood. Mol Neurobiol 50: 463-472, 2014.

169. Madrigal JL, Kalinin S, Richardson JC, and Feinstein DL. Neuroprotective actions of noradrenaline: Effects on glutathione synthesis and activation of peroxisome proliferator activated receptor delta. J Neurochem 103: 2092-2101, 2007.

170. Madrigal JL, Leza JC, Polak P, Kalinin S, and Feinstein DL. Astrocyte-derived MCP-1 mediates neuroprotective effects of noradrenaline. J Neurosci 29: 263-267, 2009.

171. Mahoney CW, Pak JH, and Huang KP. Nitric oxide modification of rat brain neurogranin. Identification of the cysteine residues involved in intramolecular disulfide bridge formation using site-directed mutagenesis. $J$ Biol Chem 271: 28798-28804, 1996.

172. Mander P, and Brown GC. Activation of microglial NADPH oxidase is synergistic with glial iNOS expression in inducing neuronal death: A dual-key mechanism of inflammatory neurodegeneration. J Neuroinflammation 2: 20, 2005.

173. Mari M, Morales A, Colell A, Garcia-Ruiz C, and FernandezCheca JC. Mitochondrial glutathione, a key survival antioxidant. Antioxid Redox Signal 11: 2685-2700, 2009.

174. Massaad CA, and Klann E. Reactive oxygen species in the regulation of synaptic plasticity and memory. Antioxid Redox Signal 14: 2013-2054, 2011.

175. Massaad CA, Washington TM, Pautler RG, and Klann E. Overexpression of SOD-2 reduces hippocampal superoxide and prevents memory deficits in a mouse model of Alzheimer's disease. Proc Natl Acad Sci U S A 106: 13576-13581, 2009.

176. Matsushita K, Morrell CN, Mason RJ, Yamakuchi M, Khanday FA, Irani K, and Lowenstein CJ. Hydrogen peroxide regulation of endothelial exocytosis by inhibition of N-ethylmaleimide sensitive factor. J Cell Biol 170: 7379, 2005.

177. Matute C. Glutamate and ATP signalling in white matter pathology. J Anat 219: 53-64, 2011.

178. McEchron MD, Weible AP, and Disterhoft JF. Aging and learning-specific changes in single-neuron activity in CA1 hippocampus during rabbit trace eyeblink conditioning. $J$ Neurophysiol 86: 1839-1857, 2001.

179. McGaughy J, Dalley JW, Morrison CH, Everitt BJ, and Robbins TW. Selective behavioral and neurochemical effects of cholinergic lesions produced by intrabasalis infusions of $192 \mathrm{IgG}$-saporin on attentional performance in a five-choice serial reaction time task. J Neurosci 22: 1905-1913, 2002.

180. Meaney MJ, O'Donnell D, Rowe W, Tannenbaum B, Steverman A, Walker M, Nair NP, and Lupien S. Individual differences in hypothalamic-pituitary-adrenal activity in later life and hippocampal aging. Exp Gerontol 30: 229-251, 1995.

181. Mecocci P, Beal MF, Cecchetti R, Polidori MC, Cherubini A, Chionne F, Avellini L, Romano G, and Senin U. Mitochondrial membrane fluidity and oxidative damage to mitochondrial DNA in aged and AD human brain. Mol Chem Neuropathol 31: 53-64, 1997.

182. Michel PP, and Hefti F. Toxicity of 6-hydroxydopamine and dopamine for dopaminergic neurons in culture. $J$ Neurosci Res 26: 428-435, 1990.
183. Miyazaki I, and Asanuma M. Dopaminergic neuronspecific oxidative stress caused by dopamine itself. Acta Med Okayama 62: 141-150, 2008.

184. Moorthy K, Sharma D, Basir SF, and Baquer NZ. Administration of estradiol and progesterone modulate the activities of antioxidant enzyme and aminotransferases in naturally menopausal rats. Exp Gerontol 40: 295-302, 2005.

185. Mori K, Ozaki E, Zhang B, Yang L, Yokoyama A, Takeda I, Maeda N, Sakanaka M, and Tanaka J. Effects of norepinephrine on rat cultured microglial cells that express alpha1, alpha2, beta1 and beta2 adrenergic receptors. Neuropharmacology 43: 1026-1034, 2002.

186. Moyer JR, Jr., Thompson LT, Black JP, and Disterhoft JF. Nimodipine increases excitability of rabbit CA1 pyramidal neurons in an age- and concentration-dependent manner. J Neurophysiol 68: 2100-2109, 1992.

187. Moyse E, Arseneault M, Gaudreau P, Ferland G, and Ramassamy C. Gender- and region-dependent changes of redox biomarkers in the brain of successfully aging LOU/ C rats. Mech Ageing Dev 149: 19-30, 2015.

188. Murakami K, Murata N, Noda Y, Tahara S, Kaneko T, Kinoshita N, Hatsuta H, Murayama S, Barnham KJ, Irie K, Shirasawa T, and Shimizu T. SOD1 (copper/zinc superoxide dismutase) deficiency drives amyloid beta protein oligomerization and memory loss in mouse model of Alzheimer disease. J Biol Chem 286: 44557-44568, 2011.

189. Murali G, and Panneerselvam C. Age-associated oxidative macromolecular damages in rat brain regions: Role of glutathione monoester. J Gerontol A Biol Sci Med Sci 62: 824-830, 2007.

190. Murray C, Sanderson DJ, Barkus C, Deacon RM, Rawlins JN, Bannerman DM, and Cunningham C. Systemic inflammation induces acute working memory deficits in the primed brain: Relevance for delirium. Neurobiol Aging 33: 603.e3-616.e3, 2012.

191. Mustafa AK, Kumar M, Selvakumar B, Ho GP, Ehmsen JT, Barrow RK, Amzel LM, and Snyder SH. Nitric oxide $S$-nitrosylates serine racemase, mediating feedback inhibition of D-serine formation. Proc Natl Acad Sci U S A 104: 2950-2955, 2007.

192. Nakae D, Akai H, Kishida H, Kusuoka O, Tsutsumi M, and Konishi Y. Age and organ dependent spontaneous generation of nuclear 8-hydroxydeoxyguanosine in male Fischer 344 rats. Lab Invest 80: 249-261, 2000.

193. Navarro A, and Boveris A. The mitochondrial energy transduction system and the aging process. Am J Physiol Cell Physiol 292: C670-C686, 2007.

194. Navarro A, Sanchez Del Pino MJ, Gomez C, Peralta JL, and Boveris A. Behavioral dysfunction, brain oxidative stress, and impaired mitochondrial electron transfer in aging mice. Am J Physiol Regul Integr Comp Physiol 282: R985-R992, 2002.

195. Nicolle MM, Gonzalez J, Sugaya K, Baskerville KA, Bryan D, Lund K, Gallagher M, and McKinney M. Signatures of hippocampal oxidative stress in aged spatial learning-impaired rodents. Neuroscience 107: 415-431, 2001.

196. Nicotra A, Pierucci F, Parvez H, and Senatori O. Monoamine oxidase expression during development and aging. Neurotoxicology 25: 155-165, 2004.

197. Noack H, Lindenau J, Rothe F, Asayama K, and Wolf G. Differential expression of superoxide dismutase isoforms in neuronal and glial compartments in the course of ex- 
citotoxically mediated neurodegeneration: Relation to oxidative and nitrergic stress. Glia 23: 285-297, 1998.

198. Norris CM, Halpain S, and Foster TC. Alterations in the balance of protein kinase/phosphatase activities parallel reduced synaptic strength during aging. J Neurophysiol 80: 1567-1570, 1998.

199. Norris CM, Halpain S, and Foster TC. Reversal of agerelated alterations in synaptic plasticity by blockade of Ltype $\mathrm{Ca}^{2+}$ channels. J Neurosci 18: 3171-3179, 1998.

200. Oh MM, Oliveira FA, and Disterhoft JF. Learning and aging related changes in intrinsic neuronal excitability. Front Aging Neurosci 2: 2, 2010.

201. Okamoto K, Tanaka H, Ogawa H, Makino Y, Eguchi H, Hayashi S, Yoshikawa N, Poellinger L, Umesono K, and Makino I. Redox-dependent regulation of nuclear import of the glucocorticoid receptor. J Biol Chem 274: 10363 $10371,1999$.

202. Oler JA, and Markus EJ. Age-related deficits in the ability to encode contextual change: A place cell analysis. Hippocampus 10: 338-350, 2000.

203. Olsen RH, Johnson LA, Zuloaga DG, Limoli CL, and Raber J. Enhanced hippocampus-dependent memory and reduced anxiety in mice over-expressing human catalase in mitochondria. J Neurochem 125: 303-313, 2013.

204. Pacher P, Beckman JS, and Liaudet L. Nitric oxide and peroxynitrite in health and disease. Physiol Rev 87: 315424, 2007.

205. Pan ZH, Zhang X, and Lipton SA. Redox modulation of recombinant human GABA(A) receptors. Neuroscience 98: 333-338, 2000.

206. Parada E, Egea J, Buendia I, Negredo P, Cunha AC, Cardoso S, Soares MP, and Lopez MG. The microglial alpha7-acetylcholine nicotinic receptor is a key element in promoting neuroprotection by inducing heme oxygenase-1 via nuclear factor erythroid-2-related factor 2. Antioxid Redox Signal 19: 1135-1148, 2013.

207. Parihar MS, Kunz EA, and Brewer GJ. Age-related decreases in $\mathrm{NAD}(\mathrm{P}) \mathrm{H}$ and glutathione cause redox declines before ATP loss during glutamate treatment of hippocampal neurons. J Neurosci Res 86: 2339-2352, 2008.

208. Pastore A, and Piemonte F. S-glutathionylation signaling in cell biology: Progress and prospects. Eur J Pharm Sci 46: 279-292, 2012.

209. Paula-Lima AC, Adasme T, and Hidalgo C. Contribution of $\mathrm{Ca}^{2+}$ release channels to hippocampal synaptic plasticity and spatial memory: Potential redox modulation. Antioxid Redox Signal 21: 892-914, 2014.

210. Penna A, Wang DS, Yu J, Lecker I, Brown PM, Bowie D, and Orser BA. Hydrogen peroxide increases GABAA receptor-mediated tonic current in hippocampal neurons. $J$ Neurosci 34: 10624-10634, 2014.

211. Perez VI, Bokov A, Van Remmen H, Mele J, Ran Q, Ikeno Y, and Richardson A. Is the oxidative stress theory of aging dead? Biochim Biophys Acta 1790: 1005-1014, 2009.

212. Perluigi M, Di Domenico F, Giorgi A, Schinina ME, Coccia R, Cini C, Bellia F, Cambria MT, Cornelius C, Butterfield DA, and Calabrese V. Redox proteomics in aging rat brain: Involvement of mitochondrial reduced glutathione status and mitochondrial protein oxidation in the aging process. J Neurosci Res 88: 3498-3507, 2010.

213. Plum L, Schubert M, and Bruning JC. The role of insulin receptor signaling in the brain. Trends Endocrinol Metab 16: 59-65, 2005.
214. Poon HF, Vaishnav RA, Getchell TV, Getchell ML, and Butterfield DA. Quantitative proteomics analysis of differential protein expression and oxidative modification of specific proteins in the brains of old mice. Neurobiol Aging 27: 1010-1019, 2006.

215. Popov D. Protein S-glutathionylation: From current basics to targeted modifications. Arch Physiol Biochem 120: 123-130, 2014.

216. Povysheva NV, and Johnson JW. Tonic NMDA receptormediated current in prefrontal cortical pyramidal cells and fast-spiking interneurons. J Neurophysiol 107: 22322243, 2012.

217. Power JM, Wu WW, Sametsky E, Oh MM, and Disterhoft JF. Age-related enhancement of the slow outward calciumactivated potassium current in hippocampal CA1 pyramidal neurons in vitro. J Neurosci 22: 7234-7243, 2002.

218. Pratico D, Uryu K, Leight S, Trojanoswki JQ, and Lee VM. Increased lipid peroxidation precedes amyloid plaque formation in an animal model of Alzheimer amyloidosis. J Neurosci 21: 4183-4187, 2001.

219. Rafnsson SB, Deary IJ, Smith FB, Whiteman MC, Rumley A, and Lowe GD, Fowkes FG. Cognitive decline and markers of inflammation and hemostasis: The Edinburgh Artery Study. J Am Geriatr Soc 55: 700-707, 2007.

220. Rahman I, Marwick J, and Kirkham P. Redox modulation of chromatin remodeling: Impact on histone acetylation and deacetylation, NF-kappaB and pro-inflammatory gene expression. Biochem Pharmacol 68: 1255-1267, 2004.

221. Raju K, Doulias PT, Evans P, Krizman EN, Jackson JG, Horyn O, Daikhin Y, Nissim I, Yudkoff M, Nissim I, Sharp KA, and Robinson MB, Ischiropoulos H. Regulation of brain glutamate metabolism by nitric oxide and Snitrosylation. Sci Signal 8: ra68, 2015.

222. Ralser M, Wamelink MM, Kowald A, Gerisch B, Heeren G, Struys EA, Klipp E, Jakobs C, Breitenbach M, Lehrach $\mathrm{H}$, and Krobitsch S. Dynamic rerouting of the carbohydrate flux is key to counteracting oxidative stress. J Biol 6: 10, 2007.

223. Ravindranath V, Shivakumar BR, and Anandatheerthavarada HK. Low glutathione levels in brain regions of aged rats. Neurosci Lett 101: 187-190, 1989.

224. Rebrin I, Forster MJ, and Sohal RS. Effects of age and caloric intake on glutathione redox state in different brain regions of C57BL/6 and DBA/2 mice. Brain Res 1127: 10-18, 2007.

225. Rebrin I, Kamzalov S, and Sohal RS. Effects of age and caloric restriction on glutathione redox state in mice. Free Radic Biol Med 35: 626-635, 2003.

226. Retamal MA, Schalper KA, Shoji KF, Bennett MV, and Saez JC. Opening of connexin 43 hemichannels is increased by lowering intracellular redox potential. Proc Natl Acad Sci U S A 104: 8322-8327, 2007.

227. Robillard JM, Gordon GR, Choi HB, Christie BR, and MacVicar BA. Glutathione restores the mechanism of synaptic plasticity in aged mice to that of the adult. PLoS One 6: e20676, 2011.

228. Robison AJ, Winder DG, Colbran RJ, and Bartlett RK. Oxidation of calmodulin alters activation and regulation of CaMKII. Biochem Biophys Res Commun 356: 97-101, 2007.

229. Rodriguez JJ, Yeh CY, Terzieva S, Olabarria M, Kulijewicz-Nawrot M, and Verkhratsky A. Complex and region-specific changes in astroglial markers in the aging brain. Neurobiol Aging 35: 15-23, 2014. 
230. Rohrdanz E, Schmuck G, Ohler S, Tran-Thi QH, and Kahl R. Changes in antioxidant enzyme expression in response to hydrogen peroxide in rat astroglial cells. Arch Toxicol 75: 150-158, 2001.

231. Roskams AJ, and Connor JR. Iron, transferrin, and ferritin in the rat brain during development and aging. $\mathrm{J} \mathrm{Neu-}$ rochem 63: 709-716, 1994.

232. Rudkouskaya A, Sim V, Shah AA, Feustel PJ, Jourd'heuil $\mathrm{D}$, and Mongin AA. Long-lasting inhibition of presynaptic metabolism and neurotransmitter release by protein Snitrosylation. Free Radic Biol Med 49: 757-769, 2010.

233. Ruppersberg JP, and Fakler B. Complexity of the regulation of Kir2.1 K+ channels. Neuropharmacology 35: 887-893, 1996.

234. Ruppersberg JP, Stocker M, and Pongs O, Heinemann SH, Frank R, and Koenen M. Regulation of fast inactivation of cloned mammalian IK(A) channels by cysteine oxidation. Nature 352: 711-714, 1991.

235. Sabens Liedhegner EA, Gao XH, and Mieyal JJ. Mechanisms of altered redox regulation in neurodegenerative diseases-Focus on S-Glutathionylation. Antioxid Redox Signal 16: 543-566, 2012.

236. Sankarapandi S, Zweier JL, Mukherjee G, Quinn MT, and Huso DL. Measurement and characterization of superoxide generation in microglial cells: Evidence for an NADPH oxidase-dependent pathway. Arch Biochem Biophys 353: 312-321, 1998.

237. Santarelli LC, Wassef R, Heinemann SH, and Hoshi T. Three methionine residues located within the regulator of conductance for $\mathrm{K}+(\mathrm{RCK})$ domains confer oxidative sensitivity to large-conductance $\mathrm{Ca}^{2+}$-activated $\mathrm{K}+$ channels. J Physiol 571: 329-348, 2006.

238. Sarter M, and Bruno JP. Cognitive functions of cortical acetylcholine: Toward a unifying hypothesis. Brain Res Brain Res Rev 23: 28-46, 1997.

239. Sato H, Takahashi T, Sumitani K, Takatsu H, and Urano S. Glucocorticoid generates ros to induce oxidative injury in the hippocampus, leading to impairment of cognitive function of rats. J Clin Biochem Nutr 47: 224-232, 2010.

240. Schafer FQ, and Buettner GR. Redox environment of the cell as viewed through the redox state of the glutathione disulfide/glutathione couple. Free Radic Biol Med 30: 1191-1212, 2001.

241. Scheinert RB, Asokan A, Rani A, Kumar A, Foster TC, and Ormerod BK. Some hormone, cytokine and chemokine levels that change across lifespan vary by cognitive status in male Fischer 344 rats. Brain Behav Immun 49: 216-232, 2015.

242. Schmitt TL, Hotz-Wagenblatt A, Klein H, and Droge W. Interdependent regulation of insulin receptor kinase activity by ADP and hydrogen peroxide. J Biol Chem 280: 3795-3801, 2005.

243. Schobitz B, de Kloet ER, Sutanto W, and Holsboer F. Cellular localization of interleukin $6 \mathrm{mRNA}$ and interleukin 6 receptor mRNA in rat brain. Eur J Neurosci 5: 1426-1435, 1993.

244. Schriner SE, Linford NJ, Martin GM, Treuting P, Ogburn CE, Emond M, Coskun PE, Ladiges W, Wolf N, Van Remmen H, Wallace DC, and Rabinovitch PS. Extension of murine life span by overexpression of catalase targeted to mitochondria. Science 308: 1909-1911, 2005.

245. Selvakumar B, Jenkins MA, Hussain NK, Huganir RL, Traynelis SF, and Snyder SH. S-nitrosylation of AMPA receptor GluA1 regulates phosphorylation, single-channel conductance, and endocytosis. Proc Natl Acad Sci U S A 110: 1077-1082, 2013.

246. Semmler A, Okulla T, Sastre M, Dumitrescu-Ozimek L, and Heneka MT. Systemic inflammation induces apoptosis with variable vulnerability of different brain regions. $J$ Chem Neuroanat 30: 144-157, 2005.

247. Sentman ML, Granstrom M, Jakobson H, Reaume A, Basu S, and Marklund SL. Phenotypes of mice lacking extracellular superoxide dismutase and copper- and zinccontaining superoxide dismutase. J Biol Chem 281: 69046909, 2006.

248. Seo JS, Park JY, Choi J, Kim TK, Shin JH, Lee JK, and Han PL. NADPH oxidase mediates depressive behavior induced by chronic stress in mice. J Neurosci 32: 9690 9699, 2012.

249. Serrano F, and Klann E. Reactive oxygen species and synaptic plasticity in the aging hippocampus. Ageing Res Rev 3: 431-443, 2004.

250. Sesti F. Oxidation of $\mathrm{K}(+)$ Channels in aging and neurodegeneration. Aging Dis 7: 130-135, 2016.

251. Sharma D, Maurya AK, and Singh R. Age-related decline in multiple unit action potentials of CA3 region of rat hippocampus: Correlation with lipid peroxidation and lipofuscin concentration and the effect of centrophenoxine. Neurobiol Aging 14: 319-330, 1993.

252. Sheu FS, Mahoney CW, Seki K, and Huang KP. Nitric oxide modification of rat brain neurogranin affects its phosphorylation by protein kinase $\mathrm{C}$ and affinity for calmodulin. J Biol Chem 271: 22407-22413, 1996.

253. Silva AR, Santos AC, Farfel JM, Grinberg LT, Ferretti RE, Campos AH, Cunha IW, Begnami MD, Rocha RM, Carraro DM, de Braganca Pereira CA, Jacob-Filho W, and Brentani H. Repair of oxidative DNA damage, cell-cycle regulation and neuronal death may influence the clinical manifestation of Alzheimer's disease. PLoS One 9: e99897, 2014.

254. Silverman HA, Dancho M, Regnier-Golanov A, Nasim M, Ochani M, Olofsson PS, Ahmed M, Miller EJ, Chavan SS, Golanov E, Metz CN, Tracey KJ, and Pavlov VA. Brain region-specific alterations in the gene expression of cytokines, immune cell markers and cholinergic system components during peripheral endotoxin-induced inflammation. Mol Med 20: 601-611, 2014.

255. Singh $\mathrm{T}$, and Newman AB. Inflammatory markers in population studies of aging. Ageing Res Rev 10: 319-329, 2011.

256. Smith CD, Carney JM, Starke-Reed PE, Oliver CN, Stadtman ER, Floyd RA, and Markesbery WR. Excess brain protein oxidation and enzyme dysfunction in normal aging and in Alzheimer disease. Proc Natl Acad Sci U S A 88: 10540-10543, 1991.

257. Snijder J, Rose RJ, Raijmakers R, and Heck AJ. Site-specific methionine oxidation in calmodulin affects structural integrity and interaction with $\mathrm{Ca}^{2+} /$ calmodulin-dependent protein kinase II. J Struct Biol 174: 187-195, 2011.

258. Sohal RS, Sohal BH, and Orr WC. Mitochondrial superoxide and hydrogen peroxide generation, protein oxidative damage, and longevity in different species of flies. Free Radic Biol Med 19: 499-504, 1995.

259. Song $\mathrm{T}$, Hatano $\mathrm{N}$, Kambe $\mathrm{T}$, Miyamoto $\mathrm{Y}$, Ihara $\mathrm{H}$, Yamamoto H, Sugimoto K, Kume K, Yamaguchi F, Tokuda M, and Watanabe Y. Nitric oxide-mediated modulation of calcium/calmodulin-dependent protein kinase II. Biochem J 412: 223-231, 2008. 
260. Sossa KG, Beattie JB, and Carroll RC. AMPAR exocytosis through NO modulation of PICK1. Neuropharmacology 53: 92-100, 2007.

261. Spencer WA, Jeyabalan J, Kichambre S, and Gupta RC. Oxidatively generated DNA damage after $\mathrm{Cu}$ (II) catalysis of dopamine and related catecholamine neurotransmitters and neurotoxins: Role of reactive oxygen species. Free Radic Biol Med 50: 139-147, 2011.

262. Spiers JG, Chen HJ, Sernia C, and Lavidis NA. Activation of the hypothalamic-pituitary-adrenal stress axis induces cellular oxidative stress. Front Neurosci 8: 456, 2014.

263. Storozhevykh TP, Senilova YE, Persiyantseva NA, Pinelis VG, and Pomytkin IA. Mitochondrial respiratory chain is involved in insulin-stimulated hydrogen peroxide production and plays an integral role in insulin receptor autophosphorylation in neurons. BMC Neurosci 8: 84, 2007.

264. Streit WJ. Microglia as neuroprotective, immunocompetent cells of the CNS. Glia 40: 133-139, 2002.

265. Streit WJ, Xue QS, Tischer J, and Bechmann I. Microglial pathology. Acta Neuropathol Commun 2: 142, 2014.

266. Suh JH, Shenvi SV, Dixon BM, Liu H, Jaiswal AK, Liu RM, and Hagen TM. Decline in transcriptional activity of Nrf2 causes age-related loss of glutathione synthesis, which is reversible with lipoic acid. Proc Natl Acad Sci $U$ S A 101: 3381-3386, 2004.

267. Sultana R, Perluigi M, and Butterfield DA. Protein oxidation and lipid peroxidation in brain of subjects with Alzheimer's disease: Insights into mechanism of neurodegeneration from redox proteomics. Antioxid Redox Signal 8: 2021-2037, 2006.

268. Takahashi A, Mikami M, and Yang J. p38 mitogenactivated protein kinase independent SB203580 block of $\mathrm{H}_{2} \mathrm{O}_{2}$-induced increase in GABAergic mIPSC amplitude. Neuroreport 18: 963-967, 2007.

269. Takahashi H, Shin Y, Cho SJ, Zago WM, Nakamura T, Gu Z, Ma Y, Furukawa H, Liddington R, Zhang D, Tong G, Chen HS, and Lipton SA. Hypoxia enhances Snitrosylation-mediated NMDA receptor inhibition via a thiol oxygen sensor motif. Neuron 53: 53-64, 2007.

270. Tanaka H, Makino Y, Okamoto K, Iida T, Yoshikawa N, and Miura T. Redox regulation of the nuclear receptor. Oncology 59 Suppl 1: 13-18, 2000.

271. Tang XD, Garcia ML, Heinemann SH, and Hoshi T. Reactive oxygen species impair Slo1 BK channel function by altering cysteine-mediated calcium sensing. Nat Struct Mol Biol 11: 171-178, 2004.

272. Tauck DL. Redox modulation of NMDA receptormediated synaptic activity in the hippocampus. Neuroreport 3: 781-784, 1992.

273. Thibault O, Gant JC, and Landfield PW. Expansion of the calcium hypothesis of brain aging and Alzheimer's disease: Minding the store. Aging Cell 6: 307-317, 2007.

274. Thiels E, Urban NN, Gonzalez-Burgos GR, Kanterewicz BI, Barrionuevo G, Chu CT, Oury TD, and Klann E. Impairment of long-term potentiation and associative memory in mice that overexpress extracellular superoxide dismutase. J Neurosci 20: 7631-7639, 2000.

275. Tombaugh GC, Rowe WB, and Rose GM. The slow afterhyperpolarization in hippocampal CA1 neurons covaries with spatial learning ability in aged Fisher 344 rats. $J$ Neurosci 25: 2609-2616, 2005.

276. Traver S, Salthun-Lassalle B, Marien M, Hirsch EC, Colpaert F, and Michel PP. The neurotransmitter noradrenaline rescues septal cholinergic neurons in culture from degeneration caused by low-level oxidative stress. Mol Pharmacol 67: 1882-1891, 2005.

277. Treuting PM, Linford NJ, Knoblaugh SE, Emond MJ, Morton JF, Martin GM, Rabinovitch PS, and Ladiges WC. Reduction of age-associated pathology in old mice by overexpression of catalase in mitochondria. J Gerontol A Biol Sci Med Sci 63: 813-822, 2008.

278. Troadec JD, Marien M, Darios F, Hartmann A, Ruberg M, Colpaert F, and Michel PP. Noradrenaline provides longterm protection to dopaminergic neurons by reducing oxidative stress. J Neurochem 79: 200-210, 2001.

279. Trotti D, Danbolt NC, and Volterra A. Glutamate transporters are oxidant-vulnerable: A molecular link between oxidative and excitotoxic neurodegeneration? Trends Pharmacol Sci 19: 328-334, 1998.

280. Umanskaya A, Santulli G, Xie W, Andersson DC, Reiken SR, and Marks AR. Genetically enhancing mitochondrial antioxidant activity improves muscle function in aging. Proc Natl Acad Sci U S A 111: 15250-15255, 2014.

281. Ursini MV, Parrella A, Rosa G, Salzano S, and Martini G. Enhanced expression of glucose-6-phosphate dehydrogenase in human cells sustaining oxidative stress. Biochem $J$ 323 (Pt 3): 801-806, 1997.

282. Utsugisawa K, Nagane $\mathrm{Y}$, Tohgi H, Yoshimura M, Ohba $\mathrm{H}$, and Genda $\mathrm{Y}$. Changes with aging and ischemia in nicotinic acetylcholine receptor subunit alpha7 mRNA expression in postmortem human frontal cortex and putamen. Neurosci Lett 270: 145-148, 1999.

283. van der Vliet A, Eiserich JP, Halliwell B, and Cross CE. Formation of reactive nitrogen species during peroxidasecatalyzed oxidation of nitrite. A potential additional mechanism of nitric oxide-dependent toxicity. $J$ Biol Chem 272: 7617-7625, 1997.

284. Van Remmen H, Ikeno Y, Hamilton M, Pahlavani M, Wolf N, Thorpe SR, Alderson NL, Baynes JW, Epstein CJ, Huang TT, Nelson J, Strong R, and Richardson A. Life-long reduction in MnSOD activity results in increased DNA damage and higher incidence of cancer but does not accelerate aging. Physiol Genomics 16: 29-37, 2003.

285. VanGuilder HD, Bixler GV, Brucklacher RM, Farley JA, Yan H, Warrington JP, Sonntag WE, and Freeman WM. Concurrent hippocampal induction of MHC II pathway components and glial activation with advanced aging is not correlated with cognitive impairment. J Neuroinflammation 8: 138, 2011.

286. Venkateshappa C, Harish G, Mahadevan A, Srinivas Bharath MM, and Shankar SK. Elevated oxidative stress and decreased antioxidant function in the human hippocampus and frontal cortex with increasing age: Implications for neurodegeneration in Alzheimer's disease. Neurochem Res 37: 1601-1614, 2012.

287. Wang N, Wang Y, Yu G, Yuan C, and Ma J. Quinoprotein adducts accumulate in the substantia nigra of aged rats and correlate with dopamine-induced toxicity in SH-SY5Y cells. Neurochem Res 36: 2169-2175, 2011.

288. Wang X, and Michaelis EK. Selective neuronal vulnerability to oxidative stress in the brain. Front Aging Neurosci 2: 12, 2010.

289. Wang X, Pinto-Duarte A, Sejnowski TJ, and Behrens MM. How Nox2-containing NADPH oxidase affects cortical circuits in the NMDA receptor antagonist model of schizophrenia. Antioxid Redox Signal 18: 1444-1462, 2013.

290. Weinshenker D, Ferrucci M, Busceti CL, Biagioni F, Lazzeri G, Liles LC, Lenzi P, Pasquali L, Murri L, Paparelli A, and 
Fornai F. Genetic or pharmacological blockade of noradrenaline synthesis enhances the neurochemical, behavioral, and neurotoxic effects of methamphetamine. $J$ Neurochem 105: 471-483, 2008.

291. Wu X, Hernandez-Enriquez B, Banas M, Xu R, and Sesti F. Molecular mechanisms underlying the apoptotic effect of KCNB1 K+ channel oxidation. J Biol Chem 288: 41284134, 2013.

292. Xia XG, Schmidt N, Teismann P, Ferger B, and Schulz JB. Dopamine mediates striatal malonate toxicity via dopamine transporter-dependent generation of reactive oxygen species and D2 but not D1 receptor activation. $J$ Neurochem 79: 63-70, 2001.

293. Xiong Y, Uys JD, Tew KD, and Townsend DM. Sglutathionylation: From molecular mechanisms to health outcomes. Antioxid Redox Signal 15: 233-270, 2011.

294. Yan LJ, Levine RL, and Sohal RS. Oxidative damage during aging targets mitochondrial aconitase. Proc Natl Acad Sci U S A 94: 11168-11172, 1997.

295. Yan LJ, and Sohal RS. Mitochondrial adenine nucleotide translocase is modified oxidatively during aging. Proc Natl Acad Sci U S A 95: 12896-12901, 1998.

296. Yang YJ, Wu PF, Long LH, Yu DF, Wu WN, Hu ZL, Fu H, Xie N, Jin Y, Ni L, Wang JZ, Wang F, and Chen JG. Reversal of aging-associated hippocampal synaptic plasticity deficits by reductants via regulation of thiol redox and NMDA receptor function. Aging Cell 9: 709-721, 2010.

297. Yao J, and Brinton RD. Estrogen regulation of mitochondrial bioenergetics: Implications for prevention of Alzheimer's disease. Adv Pharmacol 64: 327-371, 2012.

298. Yu G, Liu H, Zhou W, Zhu X, Yu C, Wang N, Zhang Y, Ma J, Zhao Y, Xu Y, Liao L, Ji H, Yuan C, and Ma J. In vivo protein targets for increased quinoprotein adduct formation in aged substantia nigra. Exp Neurol 271: 13-24, 2015.

299. Yu W, Parakramaweera R, Teng S, Gowda M, Sharad Y, Thakker-Varia S, Alder J, and Sesti F. Oxidation of KCNB1 potassium channels causes neurotoxicity and cognitive impairment in a mouse model of traumatic brain injury. J Neurosci 36: 11084-11096, 2016.

300. Zecca L, Youdim MB, Riederer P, Connor JR, and Crichton RR. Iron, brain ageing and neurodegenerative disorders. Nat Rev Neurosci 5: 863-873, 2004.

301. Zeidner G, Sadja R, and Reuveny E. Redox-dependent gating of $\mathrm{G}$ protein-coupled inwardly rectifying $\mathrm{K}+$ channels. J Biol Chem 276: 35564-35570, 2001.

302. Zhang G, Xu R, Heinemann SH, and Hoshi T. Cysteine oxidation and rundown of large-conductance $\mathrm{Ca}^{2+}$ dependent $\mathrm{K}+$ channels. Biochem Biophys Res Commun 342: 1389-1395, 2006.

303. Zhang JR, Andrus PK, and Hall ED. Age-related regional changes in hydroxyl radical stress and antioxidants in gerbil brain. J Neurochem 61: 1640-1647, 1993.

304. Zhao WQ, Chen H, Quon MJ, and Alkon DL. Insulin and the insulin receptor in experimental models of learning and memory. Eur J Pharmacol 490: 71-81, 2004.

305. Zucca FA, Segura-Aguilar J, Ferrari E, Munoz P, Paris I, Sulzer D, Sarna T, Casella L, and Zecca L. Interactions of iron, dopamine and neuromelanin pathways in brain aging and Parkinson's disease. Prog Neurobiol 155: 96119, 2017.

Address correspondence to:

Dr. Ashok Kumar

Department of Neuroscience McKnight Brain Institute

University of Florida

PO Box 100244

Gainesville, FL 32610-0244

E-mail: kash@ufl.edu

Dr. Thomas C. Foster

Department of Neuroscience McKnight Brain Institute

University of Florida

PO Box 100244

Gainesville, FL 32610-0244

E-mail: foster1@ufl.edu

Date of first submission to ARS Central, April 7, 2017; date of acceptance, May 1, 2017.

\section{Abbreviations Used}

4-HNE $=4$-hydroxynonenal

AMPA $=\alpha$-amino-3-hydroxy-5-methyl-4isoxazolepropionic acid

$\mathrm{CaMKII}=\mathrm{Ca}^{2+} /$ calmodulin-dependent protein kinase II

$\mathrm{CAT}=$ catalase

$\mathrm{DA}=$ dopamine

$\mathrm{DTNB}=5,5$-dithio-bis-2-nitrobenzoic acid

$\mathrm{DTT}=$ dithiothreitol

GABA $=$ gamma-aminobutyric acid

$\mathrm{GPx}=$ glutathione peroxidase

$\mathrm{GR}=$ glucocorticoid receptor

$\mathrm{GSH}=$ glutathione

$\mathrm{GSSG}=$ glutathione disulfide

$\mathrm{ICS}=$ intracellular $\mathrm{Ca}^{2+}$ stores

iNOS $=$ inducible nitric oxide synthase

$\mathrm{LTP}=$ long-term potentiation

$n A C h R s=$ nicotinic acetylcholine receptors

$\mathrm{NADPH}=$ nicotinamide adenine dinucleotide phosphate

NMDA $=\mathrm{N}$-methyl-D-aspartate

nNOS $=$ neuronal nitric oxide synthase

$\mathrm{NOS}=$ nitric oxide synthase

$\mathrm{NOX}=\mathrm{NADPH}$ oxidase

$\mathrm{Nrf} 2=$ nuclear factor erythroid 2-related factor

$\mathrm{PFC}=$ prefrontal cortex

$\mathrm{RNS}=$ reactive nitrogen species

$\mathrm{ROS}=$ reactive oxygen species

sAHP $=$ slow afterhyperpolarization

$\mathrm{SOD}=$ superoxide dismutase 